\title{
Review Of The Fund's Income Position For FY 2020 And FY 2021-2022
}




\title{
INTERNATIONAL MONETARY FUND
}

\section{IMF POLICY PAPER}

\section{REVIEW OF THE FUND'S INCOME POSITION FOR FY 2020 AND FY 2021-2022}

IMF staff regularly produces papers proposing new IMF policies, exploring options for reform, or reviewing existing IMF policies and operations. The following document has been released and is included in this package:

- A Press Release summarizing the views of the Executive Board as expressed during its April 27, 2020 consideration of the staff report.

- The Staff Report and Staff Supplement on the Review of the Fund's Income Position for FY 2020 and FY 2021-2022 was prepared by IMF staff and completed on April 13, 2020 for the Executive Board's consideration on April 27, 2020.

The IMF's transparency policy allows for the deletion of market-sensitive information and premature disclosure of the authorities' policy intentions in published staff reports and other documents.

\author{
Electronic copies of IMF Policy Papers \\ are available to the public from \\ http://www.imf.org/external/pp/ppindex.aspx
}

\section{International Monetary Fund Washington, D.C.}




\title{
IMF Executive Board Reviews the Fund's Income Position for FY 2020 and FY 2021-2022
}

\author{
FOR IMMEDIATE RELEASE
}

- Net operational income, mainly comprising income from lending and investments, remained strong for FY 2020 and is expected to remain so in FY 2021-2022.

- Robust income from lending reflects the ongoing elevated use of Fund credit that is expected to remain high, reflecting the Fund's support to members to help address the COVID-19 pandemic.

- An unrealized pension-related accounting adjustment that is projected in FY 2020 offsets net operational income, and the resulting loss will be absorbed through the Fund's reserves, which remain sizeable.

- The Executive Board agreed to maintain the margin for the rate of charge on IMF lending unchanged at 100 basis points for financial years FY 2021 and FY 2022.

Washington, DC - July 24, 2020: On April 27, 2020 the Executive Board of the International Monetary Fund (IMF) completed its annual review of the Fund's income position for the financial year ending April 30, 2020 (FY 2020) and set the margin for the lending rate for IMF credit for FY 2021 and FY 2022.

\section{FY 2020 Income Position}

Net operational income, of about SDR 1.4 billion (US $\$ 1.9$ billion), mainly comprising income from lending and investments, remained strong for FY 2020, broadly in line with the April 2019 estimate. Robust income from lending reflects the ongoing elevated use of Fund credit. An unrealized pension-related adjustment in FY 2020, stemming mainly from the actuarial remeasurement of staff retirement plan assets and liabilities, as required by the accounting standard IAS $19,{ }^{1}$ is expected to offset the Fund's net operational income, substantially contributing to a net loss of about SDR 1.1 billion (US\$1.6 billion) for the year. The net loss will reduce the IMF's precautionary balances, ${ }^{2}$ which are projected to amount to SDR 16.5 billion (US\$22.6 billion) at end-FY 2020.

The Executive Board also adopted other decisions that have a bearing on the Fund's finances. These included decisions to transfer income from the Fixed-Income Subaccount of the Fund's Investment Account (IA) to the General Resources Account (GRA) and to reimburse costs to the GRA.

\footnotetext{
${ }^{1}$ IAS 19 'Employee Benefits', requires the remeasurement of post-employment obligations.

${ }^{2}$ On the basis of established practice and consistent with the relevant Executive Board decision, the GRA net loss is to be charged to the special reserve.
} 
Projections of the Fund's income are currently subject to larger than normal uncertainties related to the impact of the COVID-19 pandemic on key assumptions. Uncertainties associated with the discount rate used to measure the Fund's retirement plan obligations and asset returns can have a large impact on the actual outcome, given the heightened volatility in financial markets in the wake of the pandemic. The FY 2020 annual financial statements will update for the impact of changes in key assumptions made at the time of the April projections.

\section{FY 2021-2022 Lending Rate and Income Position}

The IMF's basic lending rate for member countries' use of IMF credit is the SDR interest rate plus a fixed margin. The Board sets the margin for a period of two financial years, in line with the principle that the margin should be stable and predictable. In April 2020 the Executive Board agreed to maintain the margin for the rate of charge unchanged at 100 basis points for financial years FY 2021 and FY 2022.

As noted above, operational income for FY 2021 and FY 2022 is expected to remain strong, with projections pointing to annual net income of SDR 1.4 billion (US $\$ 1.9$ billion) and SDR 1.7 billion (US $\$ 2.4$ billion), respectively. However, these projections are subject to a high degree of uncertainty related to the scale of new lending associated with the COVID-19 economic fallout, as well as the timing and amounts of disbursements under approved arrangements included in the projections. Additional key uncertainties relate to actuarial assumptions such as the discount rate, and the performance of the Fund's investment and retirement plan asset portfolios in the wake of the pandemic. Continued positive projected net income will allow the IMF to continue to accumulate precautionary balances. 


\section{INTERNATIONAL MONETARY FUND}

April 13, 2020

\section{REVIEW OF THE FUND'S INCOME POSITION FOR FY 2020} AND FY 2021-2022

\section{EXECUTIVE SUMMARY}

This paper reviews the Fund's income position for FY 2020 and FY 2021-22. It updates the April 2019 projections and proposes decisions for the current year. The paper also includes a proposed decision to set the margin for the rate of charge for financial years 2021 and 2022.

Projections of the Fund's income are subject to larger than normal uncertainties related to the impact of the COVID-19 pandemic on key assumptions. For FY 2020, these uncertainties relate mainly to the discount rate used to measure the Fund's retirement plan obligations at April 30, 2020 and to the full year asset returns on the retirement plan and the Endowment Subaccount (EA), given the recent volatility in financial markets. For FY 2021-22, a key additional uncertainty is the scale of new lending associated with the economic fallout from the COVID-19 pandemic.

Staff currently projects a net income loss for the GRA in FY 2020. Net operational income is projected at about SDR 1.4 billion, moderately lower than the April 2019 estimate, reflecting mainly a decrease in lending income. However, the pension-related (IAS 19) expense is now estimated at about SDR 2.3 billion, resulting in a net loss of about SDR 0.8 billion.

Staff recommends that the GRA net loss for FY 2020 be charged against the special reserve. After charging the GRA FY 2020 net loss against reserves and adjusting for a one-off distribution of SDR 122 million from the SCA-1, precautionary balances are projected to amount to SDR 16.7 billion at the end of FY 2020. Staff also recommends that the margin for the rate of charge for the period FY2021-2022 be kept unchanged at 100 basis points.

The projections for FY 2021 and FY 2022 are for net income of SDR 1.4 billion and SDR 1.8 billion, respectively, excluding the impact of any pension-related gain or loss. These projections incorporate initial estimates of the impact on income of emergency lending associated with the COVID-19 pandemic. However, as noted, these projections are subject to a high degree of uncertainty. 
Approved By Andrew Tweedie
Prepared by the Finance Department in consultation with the Legal Department and the Office of Budget and Planning.

\section{CONTENTS}

INTRODUCTION

FY 2021-2022 INCOME OUTLOOK

A. Key FY 2021-2022 Income Outlook Factors $\underline{14}$

B. Review of the Margin for the Rate of Charge $\underline{18}$

\section{BOX}

1. EA Payout Policy Framework 12

\section{FIGURES}

1. Summary of Proposed Disposition Decisions 11

2. Projected Precautionary Balances Accumulation $\underline{20}$

3. EMBIG Spreads: Total Composite and Bottom Quartile $\underline{21}$

4. Projected Non-Lending Operational Income and Non-Lending Expenses $\underline{23}$

\section{TABLES}

1. Projected Income and Expenditures-FY 2020 $\underline{6}$

2. Projected Income Sources and Uses-FY 2020-2022 $\underline{15}$

3. Sensitivity Analysis-Effect of Changes in

Selected Assumptions on FY 2021 Projected Income 17

4. Income from the Margin and Reserve Accumulation $\underline{19}$

5. Long-Term Credit Market and Comparator Spreads $\underline{22}$

6. Recent Burden Sharing Adjustment Rates $\underline{24}$

\section{ANNEXES}

I. Decisions in Effect Related to the FY 2020 Income Position $\underline{27}$

II. IAS 19 Accounting for Employee Benefits and Sensitivity Analysis $\underline{28}$

III. Investment Account (IA) Performance Scenarios $\underline{31}$

IV. Assumptions Underlying the Income Projections $\underline{34}$

V. Consolidated Medium-Term Income and Expenses $\underline{35}$

VI. Reconciliation of Projected Income and Expenses-FY 2020 $\underline{36}$ 


\section{INTRODUCTION ${ }^{1}$}

1. This paper reviews the Fund's income position for FY 2020 and FY 2021-22. The paper updates the April 2019 projections and proposes decisions for the current year. The paper also includes a proposed decision to set the margin for the rate of charge under Rule I-6(4) for financial years 2021 and 2022. ${ }^{2}$

\section{The paper reflects feedback from Executive Directors in the context of recent} income-related papers. Specifically, the paper is informed by bilateral discussions with Executive Directors' offices on the Review of the Adequacy of the Fund's Precautionary Balances, ${ }^{3}$ and informal discussions with Executive Directors on the Consolidated Medium-Term Income and Expenditure Framework (in the context of the Initial Proposals for the FY 2021-FY 2023 Medium Term Budget).

\section{The paper incorporates initial estimates of potential emergency loan demand} associated with the COVID-19 pandemic. The latest baseline incorporates new Fund lending mainly in the form of emergency financing (estimated at about SDR 26 billion), reflecting the projected surge of demand for lending since the outbreak. ${ }^{4,5}$ Other income assumptions are updated to end-February and include the effects of a significant lowering of the interest rate path as well as some of the recent turbulence in financial markets, factors which have led to a sizeable reduction in the Fund's medium-term projected investment income, and a significant rise in FY 2020 pension-related (IAS 19) losses.

\section{Staff will update the income projections in this paper in a supplement closer to the} Executive Board meeting. The supplement will update lending income projections in light of the

\footnotetext{
1 Prepared by a team comprising Alexander Attie, Henrique Chociay, Marco Cobanera, Martin Gororo, Courage Gumbanjera, Parisa Kamali, Kenji Kitano, David Moore, Diviesh Nana (lead), Amadou Ndiaye, Victoria Nichipurenko, Enosa Okosodo Odibo, Joel Chiedu Okwuokei, Breno Oliveira, Diana Parra, Vidhya Rustaman, Yan Sun-Wang, Charles Xie, Jessie Yang, Wei Zhang, and Vera Zolotarskaya, under the guidance of Maria Manno and Simon Bradbury (all FIN).

2 A New Rule for Setting the Margin for the Basic Rate of Charge (11/23/11), was adopted by the Executive Board in December 2011 and was first applied in setting the margin for the rate of charge for FY 2013-14.

3 The Executive Board Meeting to discuss the Review of the Adequacy of the Fund's Precautionary Balances scheduled for mid-March was postponed to a later date in order to allow sufficient time for an assessment of the uncertainties surrounding the global economic outlook and its implications on Fund finances.

${ }^{4}$ Emergency financing, including augmentations and drawings under current precautionary arrangements, to member countries facing immediate financing needs is projected to be about SDR 26 billion based on data prepared by SPR as of March 27, 2020. Updated lending projections include disbursements to 46 member countries, made up of RFI requests (66 percent), RFI inquiries (22 percent), augmentations (4 percent), and drawings under current precautionary programs (8 percent), including SDR 2.15 billion under Morocco's Precautionary and Liquidity Line (PLL). For member countries that have RFIs only, access of 100 percent of quota is assumed, and for member countries that have an RFI-RCF blend, the RFI portion is assumed as 66.7 percent of quota. The amounts for the augmentations are based on policy notes and staff correspondence. For the projection it is assumed that the RFI requests and drawings under current precautionary programs will be disbursed by end-FY 2020, and disbursements under RFI inquiries and augmentations will be made in Q1 of FY 2021.
}

5 See IMF Makes Available $\$ 50$ Billion to Help Address Coronavirus (03/04/2020). 
emergency finance disbursed in the wake of the outbreak, incorporating the impact on income of changes in other key assumptions susceptible to the economic fallout from the pandemic, notably the pension-related (IAS 19) loss and investment returns.

5. The paper is structured as follows: The first section reviews the FY 2020 income position and the main changes from the previous projections. The second section makes proposals on the disposition of the projected FY 2020 net loss and expected charge to reserves. The third section discusses the margin for the rate of charge for FY 2021-22, updates the income projections for the period, and reviews the projected burden sharing adjustments.

\section{REVIEW OF THE FY 2020 INCOME POSITION}

6. A net loss of about SDR 0.8 billion is now projected for the GRA for FY 2020, after adjusting for a significant pension-related (IAS 19) expense (see Table 1, Line D). This compares with the positive net operational income (about SDR 1.5 billion) estimated in April 2019. The main components of the projected FY 2020 result are outlined below.

7. Net operational income of about SDR 1.4 billion is projected for FY 2020, compared with SDR 1.5 billion estimated at April 2019 (Table 1, Line C). The projections for total lending income are slightly lower than previously projected, reflecting mainly the advance repurchases during the period and the delay in certain large disbursements. The increase in non-lending income is offset partly by net administrative expenditures projected to be higher in SDR terms, and lower implicit income from interest free resources.

Total operational lending income is projected to be SDR 1.9 billion, about SDR 100 million lower than the April 2019 estimate (Table 1, Line A):

- Margin income is expected to be SDR 62 million lower than initially projected, consistent with the SDR 6.2 billion decrease in average credit outstanding. The lower average stock of credit is mainly attributable to lower than expected disbursements on account of reviews being delayed, ${ }^{6}$ as well as Greece's advance repurchases totaling SDR 2.18 billion, reducing its outstanding credit from the Fund below the surcharge threshold of 187.5 percent of quota.

- Service charges are projected at SDR 140 million, 60 percent higher than the initial estimate, mainly reflecting the expected surge in demand for new emergency lending of about SDR 26 billion, and the request by Morocco to draw on all resources available under the current PLL.

- Commitment fees are projected to be about SDR 373 million, broadly in line with the April 2019 projection. ${ }^{7}$

\footnotetext{
${ }^{6}$ For Argentina it is currently assumed that no further disbursements will take place under the 2018 SBA.

${ }^{7}$ Commitment fee income is only recognized at the expiration or cancellation of an arrangement in accordance with accounting principles. 
- Surcharges are projected to be about SDR 134 million lower than the April 2019 estimate, mainly reflecting the lower than expected disbursements under Argentina's SBA and Greece's advance repurchases; offset partly by the surcharge income from Pakistan's EFF approved in July 2019.

Investment Income - Fixed-Income Subaccount (FI): Investment income from the subaccount is currently projected at SDR 298 million compared with SDR 208 million estimated a year ago. The projections are based on actual returns to end-February and reflect the positive impact on portfolio performance of the decline in bond yields over the last year. However, this projection remains highly uncertain given recent heightened bond market volatility.

Interest free resources: Implicit earnings on the Fund's interest free resources are less than previously estimated and reflect the sharp decline in SDR interest rates in February, lowering the average rate projected to be earned for the year.

Reimbursements to the General Resources Account (GRA): In accordance with the Articles of Agreement, the GRA has to be reimbursed in respect of (i) the expenses for conducting the business of the SDR Department; and (ii) the expenses of the Special Disbursement Account on the basis of reasonable estimates. ${ }^{8}$ Moreover, on the basis of an Executive Board decision, the PRGT has to reimburse the GRA for the expenses of administering the PRGT (all expenses not only those related to SDA resources).

- The expenses of conducting the business of the SDR Department in FY 2020 are estimated at SDR 2.71 million (proposed Decision 1), in line with the earlier estimate. ${ }^{9}$

- The PRGT administrative expenses for FY 2020 are estimated at SDR 61.76 million (proposed Decision 2), slightly below earlier estimates in SDR terms.

- Staff does not propose reimbursements related to SDA resources in the Catastrophe Containment and Relief (CCR) and PRG-HIPC Trusts for FY 2020. ${ }^{10}$ In FY 2020, expenses incurred by the GRA for the CCR Trust and PRG-HIPC Trust were limited to staff's time relating to: (i) the investment and book-keeping of the resources of the trusts, (ii) HIPC debt relief operation for Somalia, and (iii) CCRT fund raising and amendments to the CCRT instrument to better facilitate assisting the poorest members facing a global pandemic, such as COVID-19.

\footnotetext{
${ }^{8}$ The process relies primarily on the Fund's Analytic Costing and Estimation System (ACES) and estimates use lagged actual data for Q4 costs.

${ }^{9}$ Consistent with paragraph 5(b) of Schedule M to the Articles of Agreement, the SDRs considered for calculating the assessment do not include SDR 16 million that, due to the overdue financial obligations of one member, are being held in an escrow account pursuant to paragraph 5(a) of Schedule M.

10 Staff has conducted a preliminary review of the methodology for SDA-related reimbursements, and given the current work demand relating to COVID-19 outbreak, had to postpone further work on this review. Staff plans to present final findings and recommendations to the Board as part of the FY 2021 review of the Fund's income position.
} 
Table 1. Projected Income and Expenditures_FY 2020

(in millions of SDRs)

\section{A. Operational income}

Lending income

Margin for the rate of charge

Service charges

Commitment fees

Surcharges

Investment income

Fixed-Income Subaccount (reserves)

Endowment Subaccount payout ${ }^{2}$

Interest free resources ${ }^{3}$

SCA- 1 and other

Reimbursements

SDR Department

PRG Trust

\begin{tabular}{|c|c|}
\hline \multicolumn{2}{|c|}{ FY2020 } \\
\hline Initial & Current \\
\hline Projections ${ }^{1}$ & Projections \\
\hline 2,418 & 2,350 \\
\hline 2,068 & 1,942 \\
\hline 735 & 673 \\
\hline 86 & 140 \\
\hline 357 & 373 \\
\hline 890 & 756 \\
\hline 208 & 298 \\
\hline 208 & 298 \\
\hline 0 & 0 \\
\hline
\end{tabular}

\section{B. Expenses}

74

Net administrative expenditures

Capital budget items expensed

Depreciation

\section{Net operational income (A-B)}

Pension and other benefits related (IAS 19) losses

\section{0}

$-2,252$

D. Net operational income/(loss) after IAS 19 adjustment

1,530

$-804$

Endowment subaccount investment income ${ }^{2}$

Net income/(loss) position

1,686

Memorandum Items:

Fund credit (average stock, SDR billions)

73.5

67.3

SDR interest rate (average, in percent)

US\$/SDR exchange rate (average)

Precautionary balances (end of period, SDR billions)

19.2

Source: Finance Department and Office of Budget and Planning

${ }^{1}$ Review of the Fund's Income Position for FY 2019 and FY 2020 (03/19/19).

${ }^{2}$ Consistent with the EA payout policy framework endorsed by the Executive Board in April 2018, the initiation of payouts is assumed to be delayed (until at least FY 2021).

${ }^{3}$ Interest free resources reduce the Fund's costs and therefore provide implicit returns. Since the Fund invests its reserves in the IA to earn a higher return, the interest free resources retained in the GRA are mainly attributable to the SCA-1, unremunerated reserve tranche positions not represented by gold holdings, and GRA income for the year not transferred to the IA. These resources reduce members' reserve tranche positions and the Fund's remuneration expense, or increase interest income if reflected in SDR holdings of the GRA, resulting in implicit income for the Fund. 
The administration of SDA resources in these trusts, including for staff time relating to the activities above, did not generate any incremental costs (i.e., costs beyond those that would have otherwise been incurred by the GRA and the PRGT). ${ }^{11}$

8. Total expenses of the GRA are estimated to be about SDR 14 million higher than previously projected due mainly to a stronger annual average U.S. dollar/SDR exchange rate compared with the April 2019 projections (Table 1, Line B). Net administrative expenditures in FY 2020 are expected to match earlier projections in U.S. dollar terms, reflecting a full utilization of the approved budget. ${ }^{12}$ However, the strengthening of the U.S. dollar against the SDR so far this year means that the expenses are converted at a rate of US $\$ 1.38$ per SDR, compared with a rate of US $\$ 1.41$ per SDR assumed in the April 2019 projection, inflating expenses in SDR terms by about SDR 18 million. This is partly offset by capital budget items expensed and the depreciation charge being slightly lower than previously projected by about SDR 4 million.

9. Based on actual developments to end-February, a projected pension-related (IAS 19) expense is currently expected to reduce income in FY 2020 by about SDR 2.3 billion. After adjusting for this expense a net operational loss is now projected for FY 2020; compared with the positive net operational income position of SDR 1.5 billion estimated in April 2019 (Table 1, Line D). ${ }^{13}$ The pension-related (IAS 19) expense currently estimated at about SDR 2.3 billion for the year results in a net loss in the GRA of over SDR 0.8 billion now projected for FY 2020.

\section{The projections for the FY 2020 pension-related (IAS 19) expense outturn remain} highly uncertain. The pension-related adjustment for FY 2020 will only be finalized after year-end and the impact on net income or loss will be reported in the Fund's annual financial statements scheduled for release in June 2020. In accordance with accounting standards, the pension-related gain or loss will be calculated using the discount rate, asset returns, and other inputs as of April 30 (the year-end reporting date). In light of the ongoing market volatility, the actual outturn could be significantly different from the projections in this paper (paragraph 19 includes a sensitivity analysis of the projected net loss to the IAS 19 gains and losses).

11. The pension-related (IAS 19) expense results from the actuarial remeasurement of the Fund's post-employment benefits plans, which by end-February had been significantly impacted by a sharp decline in discount rates during the past year. IAS 19 "Employee Benefits" is the International Financial Reporting Standard (IFRS) that deals with accounting for pension and other employee benefits. As discussed in Annex II, pension-related (IAS 19) gains and losses are volatile year-on-year, but have tended to offset over time.

\footnotetext{
${ }^{11}$ Article V, Section 12(i) requires the GRA to be reimbursed from time to time in respect of the expenses of administration of the SDA paid from the GRA by transfers from the SDA on the basis of a reasonable estimate of such expenses. No reimbursement, however, would need to be made if the administration of SDA-related resources did not incur incremental costs, i.e., where the SDA-related expenses pertain to activities that are already being carried out and paid for by the Fund from the GRA or other account.

12 See FY 2021-FY 2023 Medium-Term Budget (03/24/20).

13 See Review of the Fund's Income Position for FY 2019 and FY 2020 (03/19/19).
} 
- The FY 2020 expected pension-related (IAS 19) adjustment comprises two elements:

(i) remeasurement gains/(losses) and (ii) the net periodic pension cost, net of funding.

- Remeasurement gains and losses result from changes in the actuarially-assessed estimated future benefit obligation; and changes in the fair value of plan assets. The current year projections point to net actuarial remeasurement losses of SDR 2,083 million that are largely attributable to a significant reduction in the discount rate, offset partly by gains from changes in other actuarial assumptions (Text Table).

\begin{tabular}{|c|c|c|c|c|c|}
\hline \multicolumn{6}{|c|}{$\begin{array}{l}\text { Text Table. Reconciliation of Pension-Related (IAS 19) Gains/(Losses) } \\
\qquad \text { (in millions of SDRs) }\end{array}$} \\
\hline & \multirow{2}{*}{$\begin{array}{c}\text { FY } 2017 \\
\text { Actual } \\
\text { for year } \\
\end{array}$} & \multirow{2}{*}{$\begin{array}{l}\text { FY } 2018 \\
\text { Actual } \\
\text { for year }\end{array}$} & \multirow{2}{*}{$\begin{array}{c}\text { FY } 2019 \\
\text { Actual } \\
\text { for year }\end{array}$} & \multicolumn{2}{|c|}{ FY 2020} \\
\hline & & & & $\begin{array}{c}\text { Actual end- } \\
\text { Oct } 2019\end{array}$ & $\begin{array}{l}\text { Projected } \\
\text { for year }\end{array}$ \\
\hline Accrual vs. Funding & -247 & -140 & -125 & -86 & -170 \\
\hline Pension cost accrual & -381 & -274 & -263 & -161 & -320 \\
\hline Service cost & -354 & -274 & -273 & -155 & -309 \\
\hline Interest expense on pension liability & -308 & -340 & -355 & -188 & -377 \\
\hline Expected income on pension asset ${ }^{1}$ & 281 & 340 & 365 & 182 & 366 \\
\hline Pension funding & 134 & 133 & 138 & 75 & 150 \\
\hline Remeasurement gains/(losses) & 967 & 381 & -365 & $-1,027$ & $-2,083$ \\
\hline Discount rate change & 380 & 129 & -301 & $-1,402$ & $-2,228$ \\
\hline 'Excess return' on assets ${ }^{1}$ & 616 & 594 & -145 & 66 & -206 \\
\hline Exchange rate translation & -29 & 2 & 9 & -7 & -24 \\
\hline Other ${ }^{2}$ & 0 & -344 & 72 & 316 & 376 \\
\hline Total IAS 19 gains/(losses) & 720 & 241 & -490 & $-1,113$ & $-2,252$ \\
\hline Discount rate - at end of period (in percent) & 3.97 & 4.05 & 3.86 & 3.09 & 2.71 \\
\hline \multicolumn{6}{|c|}{$\begin{array}{l}\text { Source: Willis Towers Watson and IMF Finance Department } \\
{ }^{1} \text { Total income from plan assets comprises two components for financial reporting purposes: i) the expected } \\
\text { income on plan assets calculated using the discount rate, and included in the pension cost and ii) a gain or } \\
\text { loss included in remeasurement losses that is in 'excess' of this expected income. } \\
{ }^{2} \text { FY20: estimate of CCBR salary scale assumption adjustment; FY18: relates to adoption of } 2017 \text { UN } \\
\text { mortality table. }\end{array}$} \\
\hline
\end{tabular}

- The revaluation projections of assets for the year are based on actual and estimated portfolio performance to end-February 2020 and the end-February discount rate is projected to the end of the year. As such they remain subject to considerable uncertainty and actual outcomes may be significantly different based on developments in the wake of the pandemic.

- Recent trends in market interest rates have translated into a significant decline in the discount rate, highlighting the sensitivity of the defined benefit obligation to the discount rate. The actuarially determined remeasurement of future obligations is expected to result in a loss in FY 2020, mainly attributable to a steep decline in the discount rate since the beginning of the year that mirrors the recent downward trend in interest rates in the United States. ${ }^{14}$ The discount rate reached a historic low of 2.71 percent at

\footnotetext{
14 Yields on high quality U.S. corporate bonds have fluctuated upwards by over 100 basis points during March; and based on the current level of the discount rate, a 100 basis point change can increase or decrease the value of the pension liability by 17 to 19 percent. The end-February rate is projected to year end.
} 
end-February 2020, following a 115 basis points decline since the start of the current financial year; compared with a 19 basis points drop experienced in FY 2019. In contrast, remeasurement gains recognized in FY 2017 and FY 2018 partly reflected the effect of a discount rate increase during the respective periods (Text Table).

- The fair value of plan assets is volatile, as illustrated by recent market movements, and therefore remains unpredictable. Asset valuations reflect the recent reversal of gains recognized to end-December, and remain highly unpredictable in light of the high degree of volatility across asset classes in the portfolio. After allowing for the expected income on plan assets (included under the pension cost accrual in the table), the actuarially-determined remeasurement of plan assets is projected to be negative SDR 206 million (see Text Table).

- An additional adjustment of SDR 170 million is made, representing mainly the difference between (i) the actuarially determined annual IAS 19 expense (the increase in obligations under the staff retirement plan stemming mainly from an additional year of staff service of SDR 320 million); and (ii) the funding (cash appropriation) for the year projected at SDR 150 million.

- In light of the sensitivity of the pension-related gains and losses to changes in the discount rate, and the impact this is likely to have on the actual income outturn at year end, paragraph 19 includes a sensitivity analysis of FY 2020 net income/loss under different discount rate assumptions at year end, while keeping all other financial and demographic assumptions constant. Annex II - Figure A2.2 extends the analysis and illustrates the sensitivity of the FY 2021 and FY 2022 baseline projections to changes in the two key actuarial assumptions, viz.; the discount rate and asset returns, keeping other assumptions constant. The sensitivity analysis is illustrative in nature and does not constitute a full projection of the pension related (IAS 19) expense beyond the current year under review (i.e., FY 2020).

- Since the adoption of IAS 19 for pension and related benefits accounting, forward-looking projections about the demographic and other assumptions, and returns on the asset portfolio, have not been built into the income scenarios, due to the volatility, and hence unpredictability, of these assumptions. This is demonstrated in the FY 2020 income projections, where a significant drop in the discount rate has resulted in a large remeasurement expense. Twelve months ago, the extent of this decline would have been difficult to predict, and at that time a projected increase in the discount rate appeared to be a more feasible scenario. Given the degree of uncertainty, staff's view is that explaining the outcome of the pension-related (IAS 19) adjustment relative to a zero base is more coherent than doing so relative to a projected outcome based on hypothetical assumptions.

- Going forward, the pension-related (IAS 19) adjustment is expected to remain unpredictable and any volatility in the underlying actuarial assumptions such as the discount rate would translate into volatility in the Fund's income and reserves. However, based on past experience, in the long run, gains and losses tend to offset each other over time (see Annex II - Figure A2.1 and Text Table above). 
12. Investment income from the Endowment Subaccount (EA) for FY 2020 was estimated at SDR 167 million and includes actual performance through end-February. Since then, however, the sharp sell-off in risk assets during March has more than offset the earlier strong performance and driven the EA's investment returns into negative territory. An updated projection for the overall FY 2020 performance of the EA will be provided in the staff supplement ahead of the Board discussion. In line with the policy agreed in April 2018, staff proposes that EA investment income for FY 2020, if any, be retained in the subaccount rather than transferred to the GRA (Box 1). ${ }^{15}$

\section{IFRS 9 "Financial Instruments" which became effective for the Fund in FY 2019} requires an impairment assessment to be conducted using the 'expected credit loss' model; which aims at earlier recognition of credit losses compared to the 'incurred loss model' prescribed by the predecessor standard. The Fund's framework for assessing the need to provision has been adapted to comply with IFRS 9 and was designed to reflect the unique nature of the Fund's lending. ${ }^{16}$ Under the new framework, and considering the Fund's multilayered framework for managing credit risk, cases where provisioning for an impairment loss may need to be considered are expected to remain very rare.

14. Staff is in the process of finalizing the IFRS 9-related country assessments and at this stage no impact is expected on the FY 2020 annual financial statements. Staff plans to brief the Board again before the FY 2020 annual financial statements are finalized and will also schedule a separate informal discussion with the Executive Board later in the year, on the Fund's approach to provisioning for impairment losses in the context of its annual financial statements.

\section{DISPOSITION DECISIONS}

15. As in previous years, the Executive Board needs to consider certain decisions on the disposition of income for FY 2020. These cover the use of IA investment income earned in FY 2020, which impacts the determination of GRA net operational income or loss in FY 2020; and the charging of the expected net loss against reserves. These disposition considerations and decisions are presented in Figure 1, and discussed below, beginning with the disposition of IA investment income.

\footnotetext{
${ }^{15}$ Review of the Fund's Income Position for FY 2018 and FY 2019-2020 (04/05/18).

16 See Annex III, Review of the Fund's Income Position for FY 2019 and FY 2020 (03/19/19) for a fuller discussion on the implementation of the new standard in the Fund. 
Figure 1. Summary of Proposed Disposition Decisions

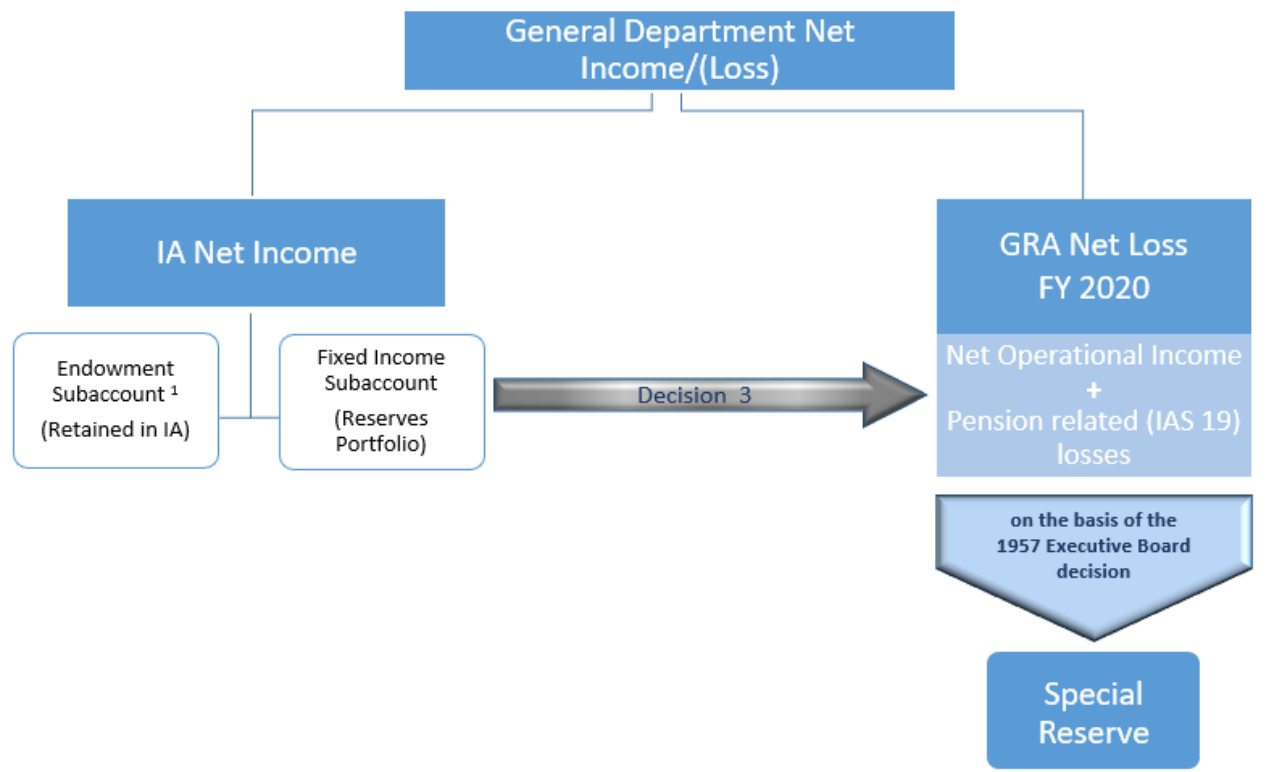

${ }^{1}$ Payouts from the Endowment Subaccount are expected to provide meaningful contributions to Fund income and will not begin until at least FY 2021 to allow for a buildup of a larger cushion of retained income in the Endowment against adverse return scenarios.

16. The use of IA income is guided by the Fund's Articles. Under Article XII, section 6 ( $f$ ) (iv), investment income from the IA may be invested, held in the IA, or used for meeting the expenses of conducting the business of the Fund. ${ }^{17}$ Staff proposes that income in the subaccounts of the IA be used as follows:

- Fixed-Income Subaccount: Consistent with past practice, staff proposes that the estimated FY 2020 income be transferred to the GRA to be used towards meeting the expenses of the Fund (proposed Decision 3). By so doing the IA income will lower the overall GRA net loss, which will be charged to the Fund's reserves as indicated in Figure 1; and

- Endowment Subaccount: In line with the EA payout policy framework endorsed by the Executive Board in April 2018, which determined that payouts would be delayed to build a larger cushion of retained income, staff proposes that any net investment income earned in the EA in FY 2020 be fully retained in the endowment and not be transferred to the GRA to be used for administrative expenses (Box 1). Based on current projections for FY 2020, this would imply that EA projected income of about SDR 167 million, reflecting actual performance to end-February, would be retained and reinvested according to the investment strategy for the Endowment Subaccount. An equivalent amount would be reflected in the special account for IA retained earnings, raising cumulative retained earnings of the IA (all attributed to the EA) to about SDR 1,263 million (proposed Decision 3). As noted, however, the actual year-end outcome for EA returns could be negative.

\footnotetext{
${ }^{17}$ Article XII, Section 6 (f)(iv). The Board could also, by a 70 percent majority of the total voting power, decide to reduce the amount of the investment in the IA (Article XII, Section 6 (f)(vi)).
} 


\section{Box 1. EA Payout Policy Framework}

In April 2018, the Executive Board endorsed an EA payout policy framework with the following key features:

- Annual payout amounts in US dollars will be determined according to a constant real payout rule.

- Annual payouts will be decided at the time of the Fund's net income disposition decisions. The initial nominal US dollar value of the payout will be aligned with the prevailing return outlook.

- The deflator for annual inflation adjustments will be the Fund's annual GED.

- The payout will be subject to a NAV-based limit which would trigger a suspension of payouts. The initial value of the payout and NAV-based limit will be decided by the Board prior to the first payout.

- Payouts will be delayed for three years (until FY 2021) to build a cushion of retained investment income.

- The retained investment income would be reassessed at the end of the three-year period.

17. The Articles permit an income deficit (or loss) to be charged against either the special reserve or the general reserve. The special reserve was established in 1957, and the relevant Board decision provides that "any administrative deficit for any fiscal year of the Fund shall be written off first against this reserve". Since the establishment of the special reserve, all operational deficits have been charged against the special reserve on the basis of the 1957 decision (with the most recent case being 2008) without the adoption of a specific Executive Board decision in any given financial year with a deficit.

\section{There would be no transfer of currencies if there is a GRA net income deficit (or loss)} for the year. Under Article XII, Section 6(f)(ii), the Fund may decide to transfer currencies to the IA only if the amount of this transfer together with amounts previously transferred to the IA do not exceed the total amount of the general reserve and the special reserve. After the charge of an actual GRA net loss to the special reserve, the combined balance in reserves would total about SDR 20.1 billion, below the net cumulative amount of transfers made thus far to the IA from the GRA of SDR 20.9 billion. Consequently, there would be no transfer of currencies to the IA.

\section{Considering the sensitivity of the income projections to several underlying} assumptions, the extent of the net loss for FY 2020 during this period of heightened financial market volatility remains unclear. ${ }^{18}$ In particular, the pension-related expense for FY 2020 remains unpredictable, mainly due to its sensitivity to the discount rate and other factors such as the volatility of plan asset returns. Based on illustrative examples, a range of outcomes are possible: for example, an increase in the current discount rate by about 50 basis points, or an increase in the asset returns of about 850 basis points, could, given the net loss currently projected for FY 2020, result in a positive estimated net income position in the GRA by year end, assuming that all other actuarial and income assumptions remained constant (Text Table).

\footnotetext{
18 The projections remain susceptible to the unpredictability of key underlying assumptions including projections for lending, investment returns, exchange rates, etc.
} 
Text Table. Illustrative Examples of FY 2020 GRA Net Income (Loss)—Sensitivity to Changes in the Discount Rate and Asset Return Assumptions 1,2,3

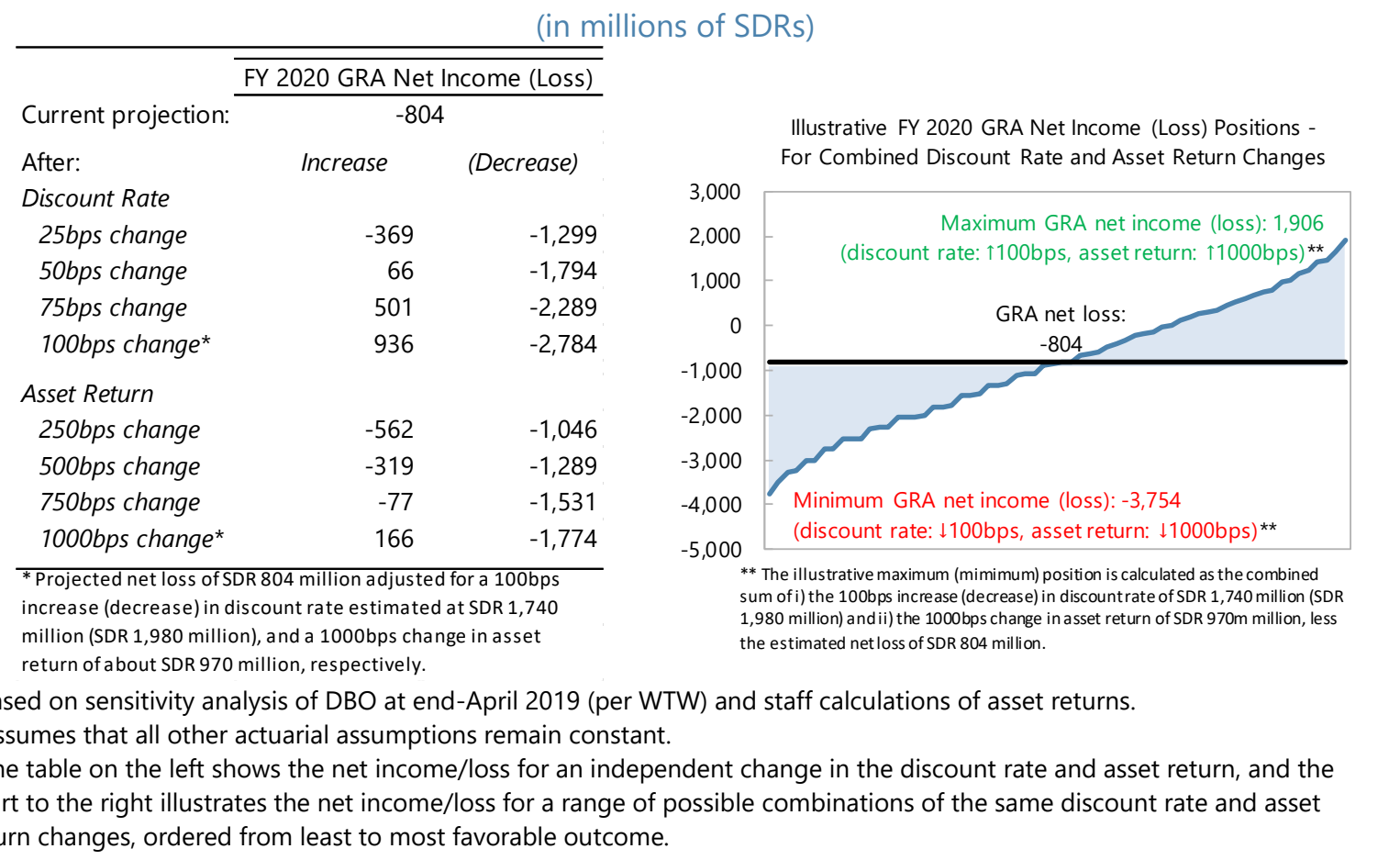

\section{The Executive Board needs to consider additional decisions on the disposition of} income in years of positive net income. These decisions cover the placement of net income to reserves and the allocation between the special and general reserve, and the transfer of currencies from the GRA to the IA, equivalent to the increase in the Fund's reserves. Under Article XII, Section 6(a), the Fund is required to determine annually how to place income between the general and special reserve and whether to distribute any income to its members. The key distinctions between the two reserves are that: (i) the special reserve cannot be distributed to members, and (ii) administrative losses should be written off first against the special reserve.

\section{The Articles of Agreement require the Fund to determine annually how to allocate its} net income. In accordance with the decision taken in FY 2018 by the Executive Board to review the allocation framework on a two-yearly cycle, a decision should be taken in FY 2020. ${ }^{19}$ However, in the absence of net income currently projected for this year, the decision will have to be deferred until the next year in which the Fund has positive net income after having replenished cumulative losses charged to the special reserve in the intervening periods.

\section{A net loss, or a small net income position, in FY 2021, could further delay the need for} a decision to allocate income between the special and general reserve. As with the allocation of the projected FY 2020 net loss, all future operational deficits would be charged against the special reserve on the basis of the 1957 decision, without the adoption of a specific Executive Board decision in any given financial year with a deficit.

\footnotetext{
${ }^{19}$ Review of the Fund's Income Position for FY 2018 and FY 2019-2020 (04/05/18).
} 


\section{FY 2021-2022 INCOME OUTLOOK}

23. The economic outlook over the coming years remains highly uncertain in the wake of the COVID-19 pandemic, as governments and policy makers worldwide take unprecedented steps to curb the fallout from the crisis. Interest rate paths across major economies have trended lower and equity markets have recently experienced considerable turbulence. Financial markets remain volatile and this volatility is expected to prevail at least in the near term, adding to the uncertainty in the Fund's income outlook. However, the deterioration in the global economic outlook is expected to result in significantly higher demand for Fund resources in the near term, resulting in higher income from lending over the medium term.

24. The projected income outlook for FY 2021-2022 as outlined below includes staff's initial analysis of potential new demand for Fund lending of about SDR 26 billion, mainly in the form of emergency financing in the wake of the COVID-19 pandemic. The lending projections incorporated in the baseline constitute estimates based on requests and inquiries for financing by member countries as of March 27 and will be updated in the supplement. Given the Fund's fluid income position through FY 2021-22 and beyond, staff will explore ways of keeping the Board informed as the situation evolves.

25. Based on current projections, the income outlook for FY 2021-2022, excluding the impact of the pension-related gain or loss, is expected to be strong. Net income is projected at about SDR 1.4 billion and SDR 1.8 billion for FY 2021 and FY 2022, respectively (Table 2). These projections assume the margin is maintained at 100 basis points (see below) and are sensitive to a number of factors including global interest rates, the timing of purchases and repurchases under existing arrangements, possible new arrangements, the U.S. dollar/SDR exchange rate, and the annual pension related adjustment as determined under IAS 19. Annex II - Figure A2.2 illustrates the sensitivity of net income to changes in key actuarial assumptions.

\section{A. Key FY 2021-2022 Income Outlook Factors}

\section{Key factors that affect the FY 2021-2022 income outlook are discussed below (see}

Table 2). A sensitivity analysis on the income effects of changes in some of the assumptions is presented in Table 3.

- Lending income. ${ }^{20}$ Margin and surcharge income is projected to increase steadily in FY 2021-22, averaging about SDR 0.9 billion and SDR 1 billion, respectively, reflecting mainly the new demand for Fund lending in the form of emergency financing and continued disbursements under the current arrangements. Colombia's precautionary arrangement that is scheduled to expire in FY 2021 is expected to contribute SDR 40 million in commitment fees, while commitment fee income of about SDR 285 million is projected for FY 2022 mainly from Mexico's Flexible Credit Line (FCL) when it expires.

\footnotetext{
${ }^{20}$ Consistent with past practice, the projections only take account of arrangements approved through end-February 2020 and not possible new arrangements, except for Argentina where it is assumed that no further disbursements will take place under the current arrangement, in line with current expectations.
} 
Table 2. Projected Income Sources and Uses-FY 2020-2022

(in millions of SDRs)

\begin{tabular}{|c|c|c|c|c|}
\hline & & FY2020 & FY2021 & FY2022 \\
\hline \multirow{14}{*}{ A. } & Operational income & 2,350 & 2,145 & 2,592 \\
\hline & Lending income & 1,942 & 1,968 & 2,354 \\
\hline & Margin for the rate of charge & 673 & 926 & 910 \\
\hline & Service charges & 140 & 59 & 16 \\
\hline & Commitment fees & 373 & 40 & 285 \\
\hline & Surcharges & 756 & 943 & 1,143 \\
\hline & Investment income & 298 & 103 & 154 \\
\hline & Fixed-Income subaccount (reserves) & 298 & 46 & 96 \\
\hline & Endowment subaccount payout ${ }^{1}$ & 0 & 57 & 58 \\
\hline & Interest free resources ${ }^{2}$ & 45 & 7 & 16 \\
\hline & SCA- 1 and other & 45 & 7 & 16 \\
\hline & Reimbursements ${ }^{3}$ & 65 & 67 & 68 \\
\hline & SDR Department & 3 & 3 & 3 \\
\hline & PRG Trust & 62 & 64 & 65 \\
\hline & Expenses & 902 & 905 & 929 \\
\hline & Net administrative expenditures & 839 & 847 & 866 \\
\hline & Capital budget items expensed & 18 & 9 & 9 \\
\hline & Depreciation & 45 & 49 & 54 \\
\hline & Net operational income (A-B) & 1,448 & 1,240 & 1,663 \\
\hline & Pension and other benefits related (IAS 19) losses ${ }^{4}$ & $-2,252$ & 0 & 0 \\
\hline \multirow[t]{3}{*}{ D. } & Net operational income/(loss) after IAS 19 adjustment & -804 & 1,240 & 1,663 \\
\hline & Endowment subaccount investment income & 167 & 130 & 91 \\
\hline & Net income position & -637 & 1,370 & 1,754 \\
\hline \multicolumn{5}{|c|}{ Memorandum items: } \\
\hline & Fund credit (average stock, SDR billions) & 67.3 & 92.6 & 91.0 \\
\hline & SDR interest rate (average, in percent) & 0.8 & 0.1 & 0.2 \\
\hline & US\$/SDR exchange rate (average) & 1.38 & 1.40 & 1.41 \\
\hline & Precautionary balances (end of period, SDR billions) & 16.7 & 18.0 & 19.6 \\
\hline \multicolumn{5}{|c|}{ Source: Finance Department and Office of Budget and Planning } \\
\hline \multicolumn{5}{|c|}{$\begin{array}{l}{ }^{1} \text { Consistent with the EA payout policy framework endorsed by the Executive Board in April 2018, the initiation of payouts } \\
\text { is assumed to be delayed (until at least FY 2021). } \\
2 \text { Interest free resources reduce the Fund's costs and therefore provide implicit returns. Since the Fund invests its reserves } \\
\text { in the IA to earn a higher return, the interest free resources retained in the GRA are mainly attributable to the SCA-1, } \\
\text { unremunerated reserve tranche positions not represented by gold holdings, and GRA income for the year not transferred to } \\
\text { the IA. These resources reduce members' reserve tranche positions and the Fund's remuneration expense, or increase } \\
\text { interest income if reflected in SDR holdings of the GRA, resulting in implicit income for the Fund. } \\
{ }^{3} \text { No incremental costs are projected in managing the SDA resources in the CCR and PRG-HIPC Trusts. } \\
{ }^{4} \text { Annex II illustrates the sensitivity of the FY } 2021 \text { and FY } 2022 \text { projections to changes in the key actuarial assumptions, } \\
\text { viz.; the discount rate and asset returns, keeping other assumptions constant. }\end{array}$} \\
\hline
\end{tabular}


- Fixed-Income Subaccount. ${ }^{21}$ Investment income is expected to decline sharply to about SDR 46 million in FY 2021 and SDR 96 million in FY 2022, contributing an average estimated return of about 0.43 percent over the two years. This is considerably lower than the April 2019 forecast and reflects the sharp decline in the level of SDR interest rates projected for FY 2021 and FY 2022. Annex III provides further discussion on the sensitivity of the returns in this portfolio to changes in global interest rates.

- Endowment Subaccount. Total EA returns are now projected to average about 3.3 percent over the medium term. However, over short time periods, income projections for the EA remain subject to considerable uncertainty given the high degree of volatility across the asset classes in which the EA is invested.

- The projections assume an initial payout of 1 percent commencing in FY 2021, which will be increased in U.S. dollar terms by the GED rate each year thereafter. This assumption is aligned with the portfolio's prevailing return outlook which has been depressed by the low level of global bond yields (Annex III - Figure A3.4b). In accordance with the discussion at the last review of the payout policy and the framework for guiding future payouts from the EA agreed by the Board, the initial value of the payout would be reassessed and decided by the Board in FY 2021 (see Box 1). ${ }^{22}$

- Based on these assumptions, the estimated payout in FY 2021 would be equivalent to about SDR 57 million (equivalent to 1 percent of the U.S. dollar value of the portfolio translated at the projected U.S. dollar/SDR exchange rate for the year). Future payouts would increase by the GED rate each year and are projected to be equivalent to about SDR 58 million in FY 2022. Income in SDR terms retained in the EA and not distributed as a payout is expected to be equivalent to about SDR 130 million and SDR 91 million, in FY 2021 and FY 2022, respectively. ${ }^{23}$

- Interest-free resources and reimbursements. Income from interest-free resources is projected to be lower reflecting the lowering of the SDR interest rate path over the medium term. Projected reimbursements are based on the FY 2020-21 estimates.

- Expenditures. Net administrative expenses are consistent with those estimated in the medium-term budget paper and continue to reflect a flat net administrative budget in real terms, that accommodates new spending priorities through reallocations and savings from

\footnotetext{
21 The balance of the Fixed-Income Subaccount corresponds to the investment of the Fund's reserves except for the gold profits and any currencies retained in the GRA.

22 Endowment payout policy framework was endorsed by the Executive Board in April 2018 (see Review of the Fund's Income Position for FY 2018 and FY 2019-2020 (04/05/18)).

${ }^{23}$ In line with the EA payout policy endorsed in April 2018, estimated investment income after the assumed payouts in FY 2021-22 is to be retained in the endowment for reinvestment and is therefore not included in the Fund's operational income (Box 1).
} 
modernization projects. ${ }^{24}$ Capital budget items expensed are expected to be lower going forward reflecting the completion of the HQ1 renewal project in FY 2020.

- Pension and other benefits related (IAS 19) gains and losses. Since the adoption of IAS 19 for pension accounting, forward-looking projections about the demographic and other assumptions, and returns on the asset portfolio, have not been built into the income scenarios, due to the volatility, and hence unpredictability, of these assumptions.

- Sensitivity Analysis. Projected income and expenses remain volatile in the near term and are particularly susceptible to changes in the underlying assumptions.

- The pension-related (IAS 19) gain or loss is highly unpredictable and can be significant: on the asset side, performance can be very volatile, and on the liability side, the defined benefit obligation (DBO) is highly sensitive to the underlying actuarial assumptions, in particular the discount rate as noted above (see Annex II - Figure A2.1). Figure A2.2 of Annex II also illustrates the sensitivity of the FY 2021 and FY 2022 baseline net income projections to changes in the key actuarial assumptions, viz;; the discount rate and asset returns, keeping other assumptions constant. Based on the specific assumptions in this illustrative analysis, net income or loss can range between SDR (4.1 and -0.4) billion in FY 2021, and SDR (4.6 and -0.1) billion in FY 2022.

- The effect of changes in other key income assumptions is summarized in Table 3.

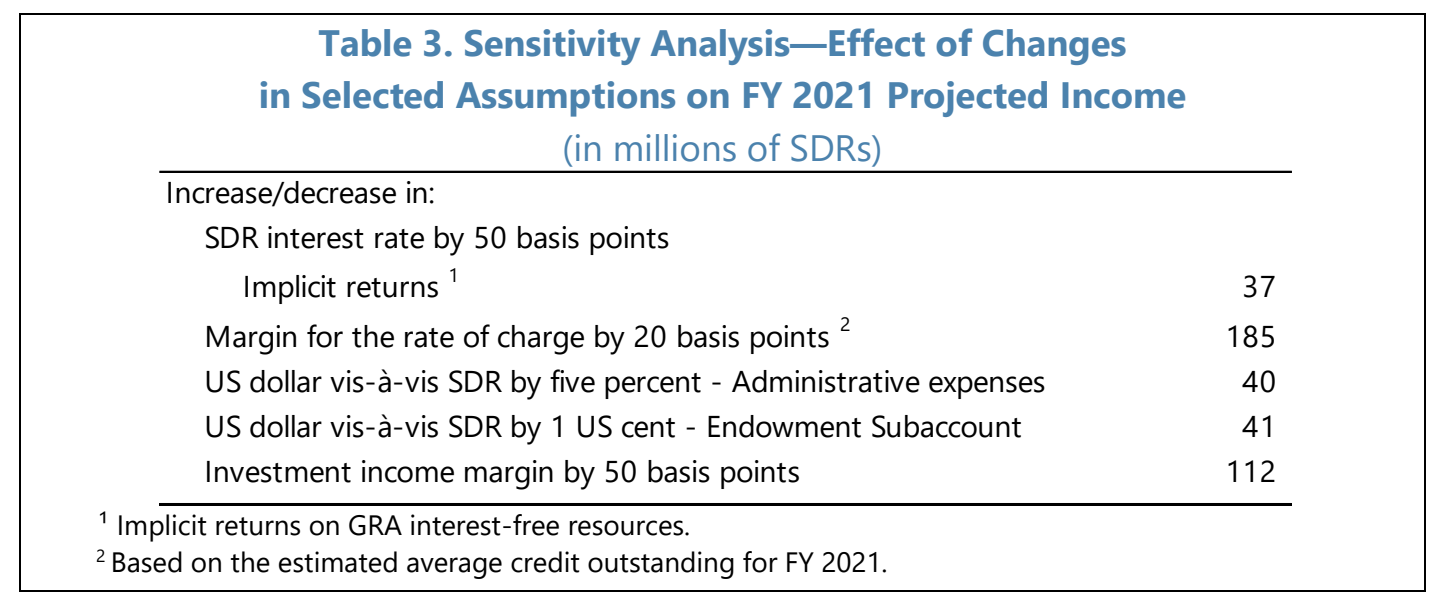

\footnotetext{
${ }^{24}$ See FY 2021-FY 2023 Medium-Term Budget (03/24/20).
} 


\section{B. Review of the Margin for the Rate of Charge}

27. The Board is to set the margin for the basic rate of charge for financial years 2021-22.

The Executive Board is required to set the margin over the SDR interest rate for two years, with a mid-period review before the end of the first year. Under the Rule I-6(4), the margin should be set at a level that is adequate to cover the Fund's intermediation costs, taking into account income from service charges, and help build up the Fund's reserves, considering the existing level of precautionary balances and the expected contribution from surcharges and commitment fees. At the same time, the level of the margin should ensure that the Fund's borrowing costs remain appropriately aligned with long-term credit market conditions. The rule also permits that, in exceptional circumstances, the margin may be set at a level other than that required to cover intermediation expenses and accumulate reserves. The margin has been set at 100 basis points since May 2008.

\section{Coverage of Intermediation Costs}

28. Lending income is projected to remain substantially in excess of intermediation costs, but is not sufficient to ensure positive reserve accumulation in FY 2020, given the large IAS 19 loss anticipated..$^{25}$ Income from service charges is projected at US\$193 million in FY 2020 (Table 4, row $B)$. An unchanged margin of 100 basis points would provide further income of about US\$928 million. These amounts compare with estimated intermediation costs of about US\$104 million in FY 2020 (Table 4, Row A). Fund-wide intermediation costs related to generally available facilities (GAF) are derived using the Fund's Analytic Costing and Estimation System (ACES). They cover direct personnel, travel and other administrative expenses, as well as indirect support and governance costs. A proportion of capital spending is also added. Estimated FY 2020 costs are higher than FY 2019, reflecting the expected increase in program engagement under the baseline; budget-to-budget this is an addition of around 10 countries relative to what was expected during the FY 2019 budget discussions.

29. Commitment fees for non-drawing arrangements and surcharges are also projected to make substantial further contributions to the Fund's lending income. Income from commitment fees and surcharges in FY 2020 are estimated at about US $\$ 515$ million and US $\$ 1,043$ million, respectively (Table 4, row E and F). Commitment fees are refundable in the event of drawings and thus income from these fees is recognized only at the expiration or cancelation of arrangements.

\section{Non-lending income is expected to cover a lower portion of non-lending expenses in} FY 2021-22 than previously projected. Non-lending income (consisting of investment income and implicit income from interest free resources) is projected to drop sharply in FY 2021-22, reflecting the recent lowering of the projections for the SDR interest rate path. Non-lending income is only expected to cover, on average, about 20 percent of the Fund's non-lending administrative expenses in FY 2021-22.

\footnotetext{
${ }^{25}$ Commitment fees are included in the analysis as a source of income that contributes to reserve accumulation. Under this approach, the analysis in setting the margin is insulated from the unpredictability of commitment fees. See paragraphs 19-20 in A New Rule for Setting the Margin for the Basic Rate of Charge (11/23/11).
} 
Table 4. Income from the Margin and Reserve Accumulation ${ }^{1}$ (in millions of US Dollars, unless otherwise indicated)

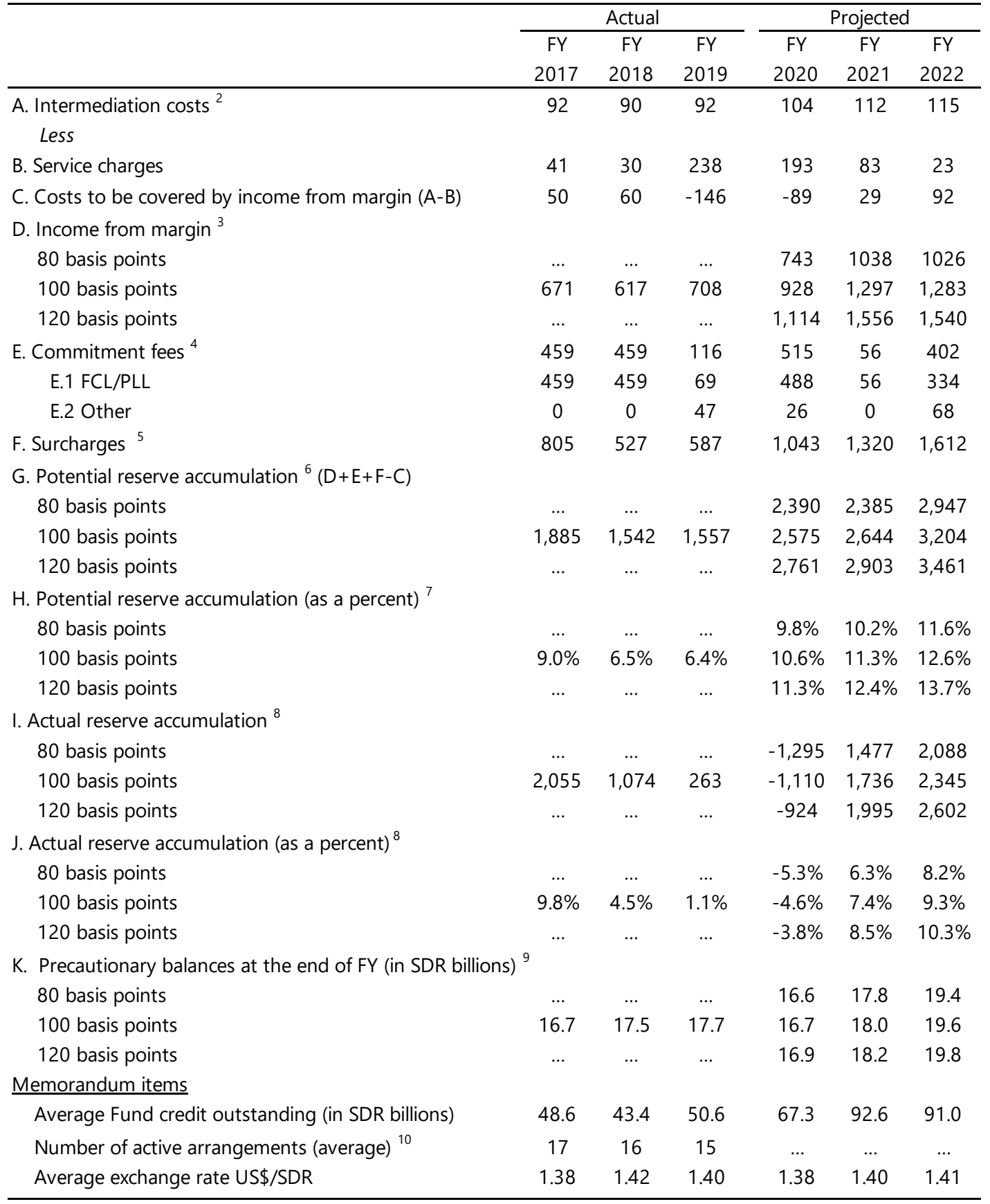

Source: Finance Department and Office of Budget and Planning

${ }^{1}$ For analytical purposes, surcharges and commitments fees are considered for reserve accumulation only.

${ }^{2}$ Costs related to the Fund's "generally available facilities."

${ }^{3}$ Derived by applying the margin against average Fund credit outstanding at the average US\$/SDR exchange rate.

${ }^{4}$ Includes commitment fees for expired or cancelled arrangements.

${ }^{5}$ Surcharges are projected on the basis of current quotas and surcharge thresholds.

${ }^{6}$ Potential reserve accumulation is derived by assuming other sources of income are sufficient to cover non-intermediation costs.

${ }^{7}$ Potential reserve accumulation as a percent of precautionary balances at the beginning of the financial year.

${ }^{8}$ Additions to or reductions in reserves based on net income or loss for the year (including actual and projected IAS 19 gains/(losses) up to FY 2020, and excludes retained Endowment Subaccount investment income).

${ }^{9}$ Precautionary balances include the Fund's reserves and SCA-1 balance less the gold endowment of SDR 4.4 billion.

${ }^{10}$ Excludes FCL and PLL arrangements. 


\section{Reserve Accumulation}

\section{Reserve accumulation is projected to resume in FY 2021 and FY 2022 despite the} decline in precautionary balances now expected in FY 2020. Table 4 first illustrates the potential reserve accumulation that would result if lending income were required solely to cover intermediation costs and provide for additional reserves (Rows $\mathrm{G}$ and $\mathrm{H}$ ). In this hypothetical scenario, potential reserve accumulation with a margin of 100 basis points would rise to 10.6 percent in FY 2020. Projected actual reserve accumulation (after taking into account the large pension related (IAS 19) loss) would be -4.6 percent of reserves in FY 2020 (Rows I and J). Precautionary balances are now projected to decline to SDR 16.7 billion by end-FY 2020, significantly lower than the SDR 19.2 billion estimated in April 2019. Table 4 further simulates reserve accumulation at alternative margins of 80 and 120 basis points, respectively.

32. Reserve accumulation is expected to proceed at a steady pace under the latest baseline projections, albeit lower than projected in April 2019. The large pension-related (IAS 19) loss in

FY 2020 and lower investment income now projected over the medium term have had an adverse effect on the accumulation of precautionary balances, however, this is partly offset by higher lending income as demand for Fund lending rises sharply in the wake of the pandemic. The pace of reserve accumulation suggests that the indicative medium-term target for precautionary balances of SDR 20 billion could be reached by FY 2023, two years later than projected in April 2019.

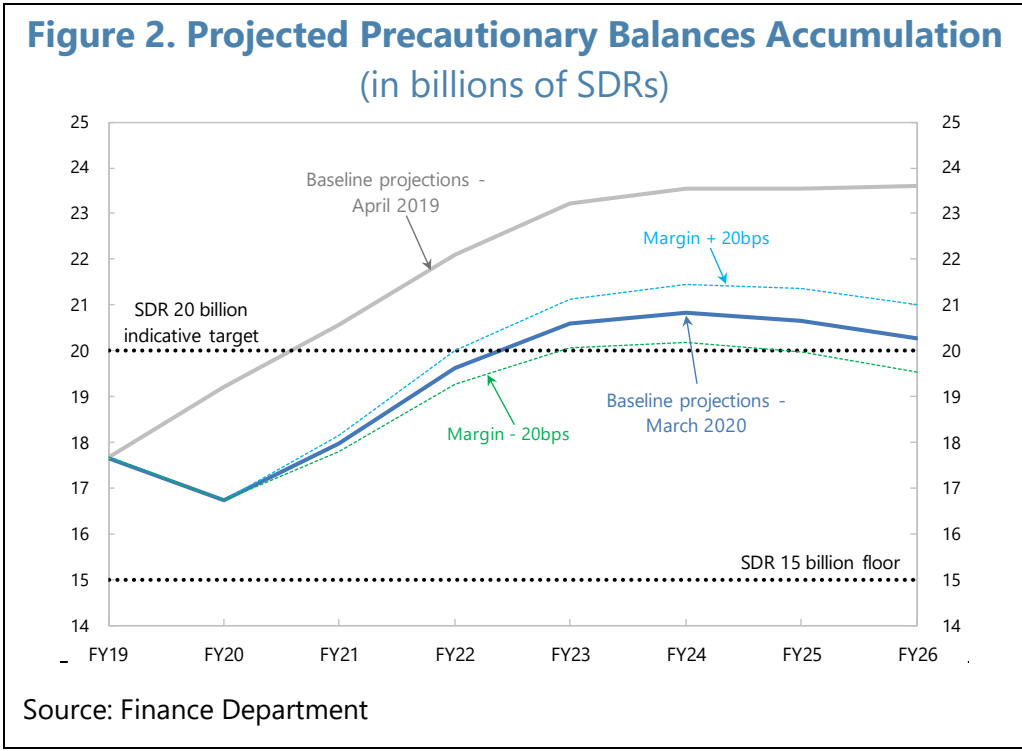

\section{Alignment of Fund Borrowing Costs with Market Conditions}

\section{Rule I-6(4) requires a cross-check of the margin's alignment with long-term credit} market conditions. ${ }^{26}$ This aims to ensure that the cost of borrowing from the Fund is not too high or low relative to the cost of long-term market funding. Staff benchmarks based on EMBI spreads provide a useful guide for this purpose, but should not be applied mechanistically without judgment on the global financial context and future developments. ${ }^{27}$ As in the past, the level of the margin is

\footnotetext{
${ }^{26}$ See A New Rule for Setting the Margin for the Basic Rate of Charge (11/23/11).

27 The EMBI spreads do not include advanced economies that currently have outstanding credit from the Fund. However, their share of overall outstanding credit as of end-January 2020 was 7 percent, down from 13 percent in April 2019. Moreover, based on currently available measures, staff continues to view the EMBI-based measure as the most appropriate metric of long-term market conditions. See Annex II, Review of the Fund's Income Position for FY 2014 and FY 2015-2016 (04/07/14).
} 
compared to the lowest quartile of EMBI spreads (reflecting the spreads for the more creditworthy borrowers within the sample) as a proxy measure to account for the lower credit risk the Fund faces as a cooperative public policy institution. ${ }^{28}$ Market borrowing spreads reflect a country-specific, time-varying credit risk premium. While the Fund also bears credit risk when it lends to member countries, it uses a multilayered framework-including policies on access, program design, and conditionality to support members' BoP adjustment, and its de facto preferred creditor status, among other elements - to mitigate such credit risk.

\section{The cost of Fund credit at the current margin remains broadly in line with the staff benchmarks for long-term credit market conditions. Since the previous review in April 2019,} EMBI spreads have declined through end-2019, then slightly picked up through February 2020. From a medium-term perspective, the five-year rolling average of the spreads remains broadly unchanged (Figure 3), but could be expected to increase in the near term if current conditions persist. At end-February 2020, the five-year median for the lowest quartile EMBI spreads stood at 153 basis points (53 basis points above the current margin) (Table 5). Therefore, for the moment, staff considers that the margin remains aligned with long-term credit market conditions.

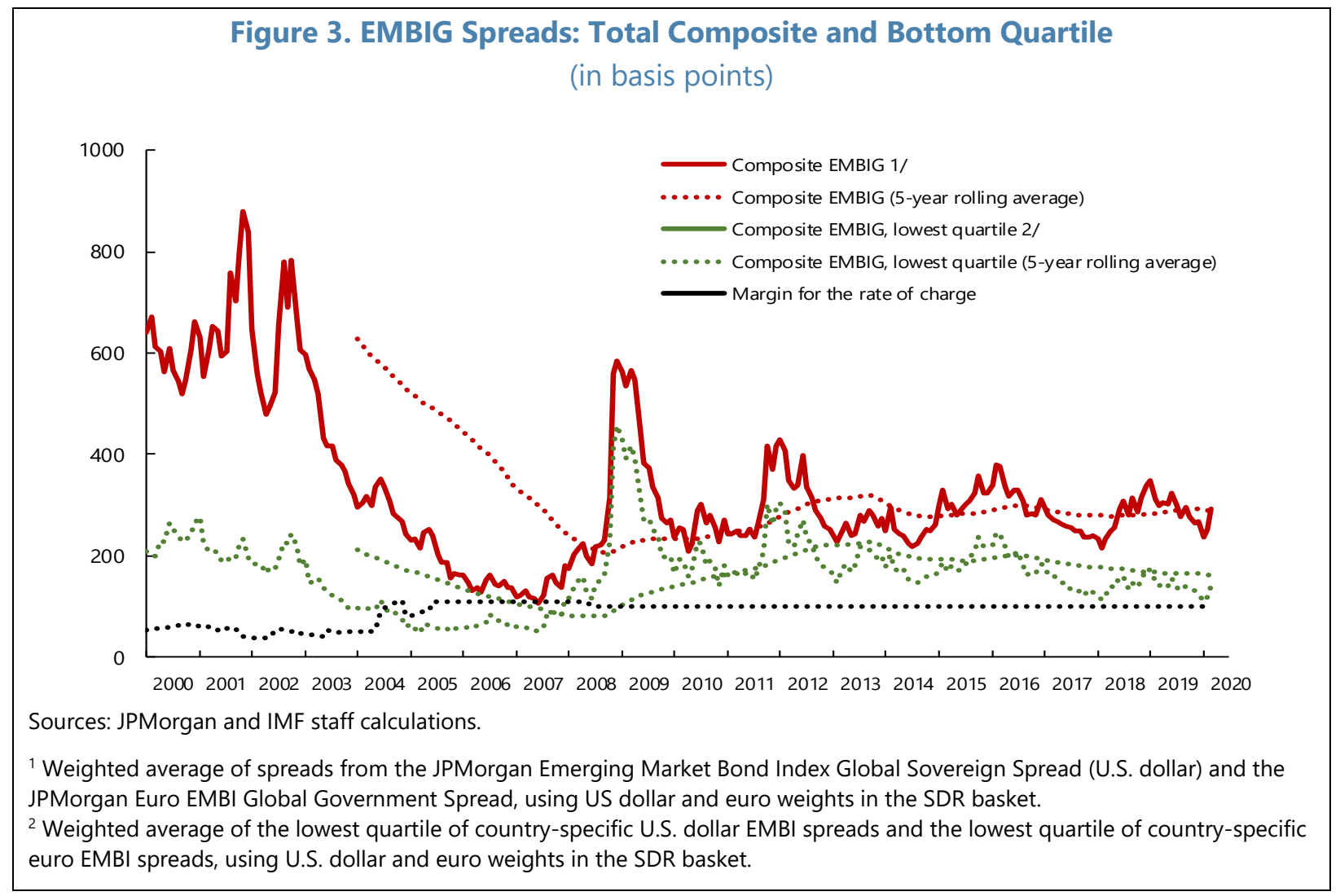

\footnotetext{
${ }^{28}$ In the past, staff has also adjusted spreads to account for the maturity difference between the SDR interest rate (based on a floating rate composed of three-month instruments) and the EMBI measures (based on medium-term fixed interest rate instruments). As this estimation has been subject to a few conceptual and data limitations, and the resulting adjustments have been marginal (in the magnitude of ten basis points), the assessment of the margin in this review is based solely on credit-risk adjusted EMBI spreads.
} 


\begin{tabular}{|c|c|c|c|}
\hline \multicolumn{4}{|c|}{$\begin{array}{l}\text { Table 5. Long-Term Credit Market and Comparator Spreads } \\
\text { (median spread unless otherwise noted, in SDR-equivalent basis points) }\end{array}$} \\
\hline & $2006-2010$ & $2011-2015$ & Mar 2015 - Feb 2020 \\
\hline \multicolumn{4}{|l|}{ Composite EMBI Global 1/ } \\
\hline 5-year average & 245 & 289 & 290 \\
\hline 5-year median & 219 & 277 & 292 \\
\hline \multicolumn{4}{|l|}{ Composite EMBI Global, Lowest Quartile 2/ } \\
\hline 5-year average & 165 & 195 & 161 \\
\hline 5-year median & 151 & 180 & 153 \\
\hline \multicolumn{4}{|l|}{ Memorandum items } \\
\hline Past borrowers (5-year median) 3/ & 237 & 302 & 269 \\
\hline Margin for the rate of charge (5-year average) & 104 & 100 & 100 \\
\hline \multicolumn{4}{|c|}{ Sources: Bloomberg, JP Morgan and IMF staff calculations. } \\
\hline \multicolumn{4}{|c|}{$\begin{array}{l}{ }^{1} \text { Weighted average of spreads from the JPMorgan Emerging Market Bond Index Global Sovereign Spread (U.S. dollar) and the } \\
\text { JPMorgan Euro EMBI Global Government Spread, using US dollar and euro weights in the SDR basket. } \\
{ }^{2} \text { Weighted average of the lowest quartile of country-specific U.S. dollar EMBI spreads and the lowest quartile of country-specific } \\
\text { euro EMBI spreads, using U.S. dollar and euro weights in the SDR basket. } \\
{ }^{3} \text { Weighted average of the median of country-specific U.S. dollar EMBI spreads and the median of country-specific euro EMBI } \\
\text { spreads, using U.S. dollar and euro weights in the SDR basket, considering a sample of members with Fund GRA arrangements } \\
\text { between } 2000 \text { and } 2019 \text {. }\end{array}$} \\
\hline
\end{tabular}

\section{Exceptional Circumstances Clause}

\section{In an environment of persistently low global interest rates, the exceptional} circumstances clause under Rule I-6(4) remains applicable for purposes of setting the margin for the rate of charge. The new Rule I-6(4), which was amended as part of the Fund's New Income Model, was designed to move away from reliance on lending income for financing the Fund's non-lending activities, i.e., non-lending income was expected to cover non-lending activities while lending income was to cover intermediation costs and contribute to reserve accumulation. However, investment income, the main source of the Fund's non-lending income is lower than previous projections reflecting a combination of lower interest rates and slower reserve accumulation. Payouts from the Endowment Subaccount are also expected to provide a contribution from FY 2021, but the baseline scenario now assumes a lower 1 percent payout. Therefore, for the time being, the Fund will need to continue to rely on its lending income to cover a significant portion of its non-lending operating costs.

\section{Against this background, the margin for FY 2021-22 will again need to be set under} the exceptional circumstances clause. Non-lending income (consisting of investment income and implicit income from interest free resources) is projected to decline in FY 2021 and gradually increase in the medium term, covering about 29 percent of the Fund's non-lending administrative expenses by FY 2026. The projected coverage ratio assumes the commencement of payouts from the Endowment Subaccount in FY 2021 in line with the framework endorsed by the Board (Figure 4). The need to cover the residual non-lending expenses by income from the margin reduces its potential contribution to the Fund's reserve accumulation. 
Figure 4. Projected Non-Lending Operational Income and Non-Lending Expenses ${ }^{1}$

(in millions of SDR, percent)

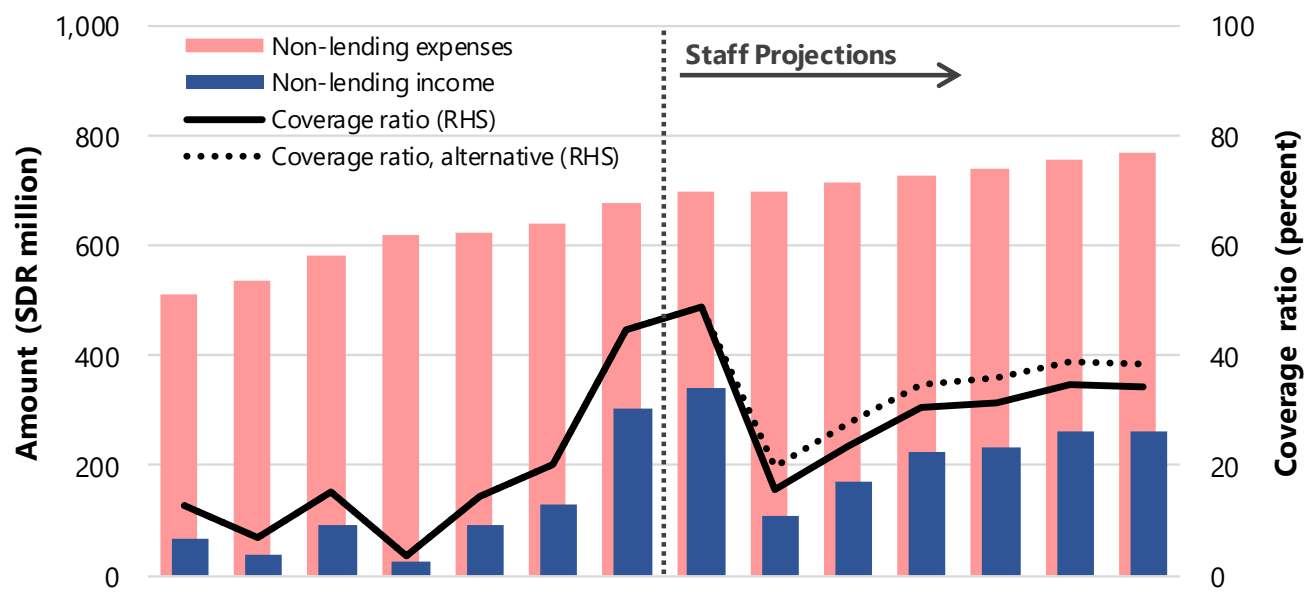

FY 13 FY 14 FY 15 FY 16 FY 17 FY 18 FY 19 FY 20 FY 21 FY 22 FY 23 FY 24 FY 25 FY 26

Source: Finance Department and Office of Budget and Planning

${ }^{1}$ Non-lending operational income comprises investment income and implicit income from interest free resources. Baseline projection assumes 1 percent payout from the Endowment Subaccount commencing in FY 2021. Alternative projection assumes 1.5 percent payout. Non-lending expenses are net administrative expenditures less intermediation costs related to generally available facilities, PRGT and SDR Department.

37. Based on the above assessment, staff proposes that the margin for the rate of charge be maintained at 100 basis points for FY 2021-22 (proposed Decision 4). The current level of the margin also appears broadly aligned with long-term credit market conditions. In line with Rule I-6(4), Directors will have an opportunity to review the level of the margin before the end of FY 2021.

\section{Burden sharing adjustments reflect the current levels of overdue obligations and} lending. The projected burden sharing rates in Q4 FY 2020 stand at 0.3 basis points for both debtors and creditors, and together with the 5 basis point floor on the SDR interest rate aims to preserve a minimal capacity of equal burden sharing for protecting the Fund's balance sheet, while limiting potential departures of the SDR interest rate from market interest rates. ${ }^{29}$ The burden sharing decision allows for a "carry-forward" of excess amounts generated from a minimum adjustment to the rate of charge and the rate of remuneration. ${ }^{30}$ If the amounts brought forward are sufficient to offset deferred charges in subsequent quarter(s), no adjustments are necessary for such quarters (see Table 6). For a report on the cumulative burden sharing adjustments (by member) at end-January 2020 refer to www.imf.org/external/np/fin/tad/query.aspx.

\footnotetext{
29 Under the burden sharing mechanism, where creditors and debtors together generate equal amounts to cover deferred charges, a minimum positive SDR interest rate is required for the mechanism to operate.

30 See The Fund's Income Position for FY 2010-Midyear Review (12/08/09), paragraphs 8-10.
} 


\section{The projected burden sharing adjustment rates will be updated in the supplement to}

the paper. The decline in interest rates and the clearance of Somalia's arrears will affect the Fund's burden sharing adjustment rates and its capacity. The decline in the residual burden sharing capacity is expected to reflect the sharp fall in SDR interest rate since end-February, offset partly by the recent clearance of Somalia's arrears.

\begin{tabular}{|c|c|c|c|c|c|c|c|c|}
\hline $\begin{array}{r}\text { Table 6. Re } \\
\text { (in ba }\end{array}$ & $\begin{array}{l}\text { t Burc } \\
\text { points }\end{array}$ & $\begin{array}{l}\text { en Sha } \\
\text { unless }\end{array}$ & $\begin{array}{l}\text { ring } \mathbf{A} \\
\text { othern }\end{array}$ & $\begin{array}{l}\text { djustm } \\
\text { vise stat }\end{array}$ & $\begin{array}{l}\text { ent Rat } \\
\text { ted) }\end{array}$ & & & \\
\hline & FY13 & FY14 & FY15 ${ }^{3}$ & FY16 & FY17 & FY18 & FY19 & FY20 \\
\hline & & & & & & & & Projected \\
\hline \multicolumn{9}{|l|}{ Rate of Remuneration ${ }^{1}$} \\
\hline Deferred charges & $--^{2}$ & $--^{2}$ & 0.300 & 0.575 & 0.375 & 0.500 & 0.500 & 0.300 \\
\hline \multicolumn{9}{|l|}{ Rate of Charge ${ }^{1}$} \\
\hline Deferred charges & $--^{2}$ & $--^{2}$ & - & - & 0.150 & 0.500 & 0.500 & 0.350 \\
\hline Average SDR interest rate (in percent) & 0.09 & 0.09 & 0.061 & 0.051 & 0.187 & 0.678 & 1.037 & 0.767 \\
\hline Average basic rate of charge (in percent) & 1.09 & 1.09 & 1.061 & 1.051 & 1.187 & 1.678 & 2.037 & 1.767 \\
\hline \multicolumn{9}{|l|}{ Source: Finance Department } \\
\hline \multicolumn{9}{|c|}{$\begin{array}{l}{ }^{1} \text { The average rates have been calculated using the quarterly burden sharing rates and SDR interest rates. No adjustments to the } \\
\text { rate of charge in FY 2015, FY 2016, and the first two quarters in FY } 2017 \text {. } \\
{ }^{2} \text { Annual average rate calculated is less than } 0.5 \text { basis points. (prior to October 2014, the minimum burden sharing adjustment rate } \\
\text { was set at } 1 \text { basis point). }\end{array}$} \\
\hline
\end{tabular}




\section{Proposed Decisions}

\section{Decisions Pertaining to FY 2020}

- Decision 1 provides for the assessment on SDR Department participants for the reimbursement of the General Department for the expenses of conducting the business of the SDR Department in FY 2020.

- Decision 2 provides for the reimbursement to the General Resources Account for the total amount of the cost of administering the PRGT in FY 2020.

- Decision 3 provides for the transfer of income from the Fixed-Income Subaccount of the Investment Account to the General Resources Account for use in meeting FY 2020 administrative expenses. The income of the Endowment Subaccount for FY 2020, if any, shall be retained. ${ }^{1}$

\section{Decisions Pertaining to FY 2021-22}

- Decision 4 sets the rate of charge on the use of Fund's resources for FY2021-2022 at 100 basis points over the SDR interest rate.

Decisions 1 to 3 may be adopted by a majority of the votes cast. Decision 4 may be adopted by a 70 percent majority of the total voting power.

\section{Decision 1. Assessment under Article XX, Section 4 for FY 2020}

Pursuant to Article XVI, Section 2 and Article XX, Section 4 of the Articles of Agreement and Rule T-2 of the Fund's Rules and Regulations, it is decided that:

(i) The General Department shall be reimbursed for the expenses of conducting the business of the SDR Department for the period of May 1, 2019 through April 30, 2020; and (ii) An assessment shall be levied on all participants in the SDR Department. The special drawing right holdings accounts of participants shall be debited on April 30, 2020 with an amount equal to 0.00132887 percent of their net cumulative allocations of special drawing rights. The total assessment shall be paid into the General Department.

\footnotetext{
${ }^{1}$ While income is projected in the EA for FY 2020, returns are volatile, and the likelihood of negative returns remain as indicated in paragraphs 12 and 16.
} 


\section{Decision 2. PRG Trust Reimbursement for FY 2020}

In accordance with paragraph 3 of Decision No. 8760-(87/176), adopted on December 18, 1987, an amount equivalent to SDR 61.76 million, representing the cost of administering the Poverty Reduction and Growth Trust (PRGT) for FY 2020, shall be transferred from the Reserve Account of the PRGT (through the Special Disbursement Account) to the General Resources Account.

\section{Decision 3. Transfer of Investment Income for FY 2020 to General Resources Account}

The income of the Fixed-Income Subaccount of the Investment Account for FY 2020 shall be transferred to the General Resources Account for use in meeting the expenses of conducting the business of the Fund during FY 2020. The income of the Endowment Subaccount for FY 2020, if any, shall be retained in the Endowment Subaccount and invested according to the Rules and Regulations for the Investment Account.

\section{Decision 4. The Rate of Charge on the Use of Fund Resources for FY 2021 and FY 2022}

Pursuant to Rule I-6(4)(a), last sentence of the Fund's Rules and Regulations, the rate of charge for FY2021 and FY 2022 shall be 100 basis points over the SDR interest rate under Rule T-1 of the Fund's Rules and Regulations. 


\section{Annex I. Decisions in Effect Related to the FY 2020 Income Position ${ }^{1}$}

\section{Decisions in Effect}

The Executive Board has taken the following decisions affecting the Fund's income position for FY 2020:

Rate of Charge

The margin for calculating the basic rate of charge in FY 2020 was set in 2018 at 100 basis points for a period of two years (FY 2019-20). ${ }^{1}$ This decision was adopted under the exceptional circumstances clause of Rule I-6(4), which allows the margin for calculating the basic rate of charge to be set at a level other than that which is adequate to cover the estimated intermediation expenses of the Fund and to generate an amount of net income for placement to reserves.

Burden Sharing for Deferred Charges ${ }^{2}$

Income losses resulting from unpaid charges are shared equally between debtor and creditor members under the burden sharing mechanism largely pursuant to decisions taken in 2000 and 2009. Unless amended by the Board, this mechanism will continue for as long as overdue obligations to the Fund persist. ${ }^{3}$

Special Charges ${ }^{4}$

For overdue repurchases, the special rate of charge is set to equal the excess, if any, of the SDR interest rate over the basic rate of charge (Paragraph 3 of Decision No. 8165-(85/189), as amended). Pursuant to Rule I-6(4), the basic rate of charge "shall be determined at the beginning of each financial year as the SDR interest rate under Rule T-1 plus a margin expressed in basis points". Since under the current system for setting the basic rate of charge, that rate is always in excess of the SDR interest rate, members are not subject to special charges on their overdue repurchases.

In FY 2019 the Board reviewed the system of special charges and adopted a decision to amend Section VI of the 1985 decision on special charges, to shift the requirement for regular review from the annual review of the Fund's income position to the five-yearly Review of the Fund's Strategy on Overdue Financial Obligations. Accordingly, the next review of the special charges framework would be due by 2022 but could take place sooner if circumstances warrant.

${ }^{1}$ Decision No. 16363-(18/36), adopted on April 25, 2018.

2 Decision No. 12189-(00/45), adopted on April 28, 2000, as amended.

${ }^{3}$ See Recent fall in the SDR Interest Rate - Implications and Proposed Amendments to Rule T-1 (10/16/14).

${ }^{4}$ The requirement for an annual review of special charges was amended at last year's discussion of the Fund's income position. See Review of the Fund's Income Position for FY 2019 and FY 2020 (03/19/19).

\footnotetext{
${ }^{1}$ See Review of the Fund's Income Position for FY 2018 and FY 2019-2020 (04/05/18).
} 


\section{Annex II. IAS 19 Accounting for Employee Benefits and Sensitivity Analysis}

IAS 19 is the International Financial Reporting Standard (IFRS) that deals with accounting for pension and other employee benefits in the financial statements of the Employer (see Box A2.1). Reporting requirements under the standard introduce an additional source of volatility to Fund income as the full impact of remeasurement gains and losses incurred during the year is reflected in the annual pension-related (IAS 19) adjustment.

Figure A2.1 illustrates the Fund's remeasurement gains and losses for FY 2000-20 (restated retrospectively under amended IAS 19 for FY 2000-13). Historically, variances in the discount rate used to derive the net present value of pension obligations and movements in the fair value of pension assets have had the largest impact on changes in the funded status of the defined benefit pension plan. Any volatility in the underlying actuarial assumptions can translate into volatility in the Fund's reserves and income. As a result, on an annual basis, remeasurement gains and losses can be substantial; however, these tend to offset each other over time, as evidenced recently over the last few years.

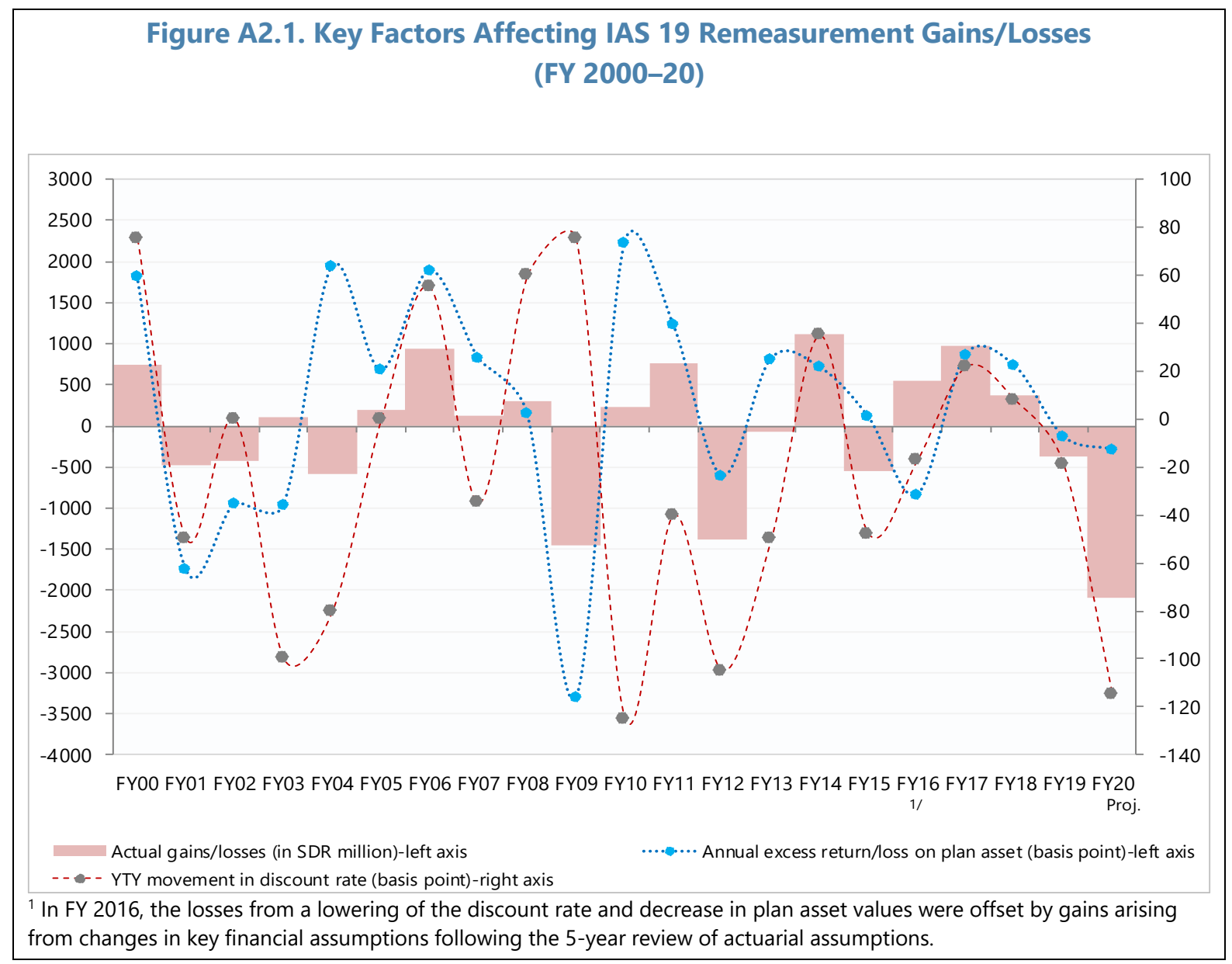


Going forward, pension-related gains and losses are expected to remain unpredictable and any volatility in the underlying actuarial assumptions would translate into volatility in the Fund's income and reserves.

\section{Box A2.1. IAS 19-Background to the Standard and Accounting in the Fund}

Since the adoption of IFRS in FY 2000, the Fund has followed IAS 19 in accounting for employee benefits. The objective of IAS 19 is to ensure that the liability associated with services provided by employees in exchange for benefits to be paid in the future and the related annual expense is properly recognized by the employer in its financial statements. IAS 19 prescribes the accounting by employers for (i) short-term employee benefits (e.g., salaries and wages); and (ii) post-employment benefits (e.g., pension, post-retirement health benefits, and termination grants). The employer recognizes an expense for shortterm employee benefits in the period in which an employee has rendered services. Cash outflows associated with long-term benefits are subject to a high degree of uncertainty and are actuarially determined.

To meet the benefit obligations associated with post-employment and long-term benefits, the Fund has sponsored a defined benefit plan (Staff Retirement Plan) and a separate Retired Staff Benefits Investment Account. The Fund reports on the balance sheet a net asset or liability equal to the difference between the fair value of plan assets and the net present value of the defined benefit obligation. To determine the present value of the defined benefit obligation, the Fund discounts projected future cash outflows by applying demographic assumptions (e.g., mortality and employee turnover), and financial assumptions (e.g., the discount rate, salary increases, inflation rate, and future medical costs). Changes in underlying assumptions from year to year give rise to actuarial gains or losses (e.g., a reduction in the discount rate, and all else being equal, would result in a higher defined benefit obligation that contributes to a remeasurement loss). ${ }^{1}$ The change in the net asset (or liability), after taking into account annual pension costs, the employer's contributions to the plans, and remeasurement gains and losses, determines the IAS 19 gain or loss for the year.

In FY 2014, IAS 19 was amended eliminating the "corridor method." As a result, all gains and losses arising from changes in actuarial assumptions are recognized in the year incurred. The amendment was implemented retrospectively such that a one-time adjustment for the cumulative unrealized actuarial losses was charged against the reserves on May 1, 2013 (start of the financial year), bringing the Fund's net asset (or liability) and reserves to the same level as if the Fund had never chosen to apply the "corridor method."

\section{Accounting vs. Funding}

The actuarial methods under IAS 19 to measure the IAS 19 expense in the Fund's financial statements are different from the actuarial method used to determine the Fund's annual contribution for the pension plans (i.e., the funding requirement). Therefore, the accounting for employee benefits differs between the Fund's financial statements (accrual basis) and the administrative budget (cash basis for employer's contributions). The resulting differences can be substantial but should net to zero over the life of the pension and benefit plans, as from an accounting perspective the net IAS 19 pension expenses necessarily equal the employer's funding over time.

${ }^{1}$ Under IAS 19, the discount rate should be determined by reference to market yields at the end of the reporting period, on "high quality corporate bonds". 


\section{Sensitivity Analysis-Illustrative Scenarios of FY 2021-22 Net Income Projections}

Figure A2.2 illustrates the sensitivity of the baseline scenario projections to changes in two key actuarial assumptions, viz.; the discount rate and asset returns. If the projections are more positive with rising discount rates (from 2.71 percent, to 3.21 percent by the end of FY 2021, and 3.71 percent by the end of FY 2022) and asset gains (10 percent annual returns), the pension expense would decrease, raising projected overall net income to SDR 3.2 billion by the end of FY 2021 and SDR 3.7 billion by the end of FY 2022. By contrast under adverse projection scenarios with lower discount rate and asset movements (2.21 percent discount rate at the end of FY 2021 and 1.71 percent by the end of FY 2022 and 2 percent annual returns), the pension expense would increase, reducing projected net income to SDR 0.6 billion by the end of FY 2021 and SDR 0.9 billion by the end of FY 2022. The scenarios in Figure A2.2 are purely illustrative in nature and analyze the sensitivity of the baseline to changes in the discount rate and asset returns, while keeping all other key financial and demographic assumptions constant; therefore, the actual outcomes could vary significantly from the projections.

Also shown below is the impact on the net income projections, of a more substantial change in the discount rate of 100 basis points (i.e., by an additional 50 basis points), in FY 2021 and FY 2022.

\section{Figure A2.2. Sensitivity of Net Income Projections to Changes in the Discount Rate and Asset Returns - Illustrative Scenarios (FY 2021-22) ${ }^{1}$ \\ (in millions of SDR)}

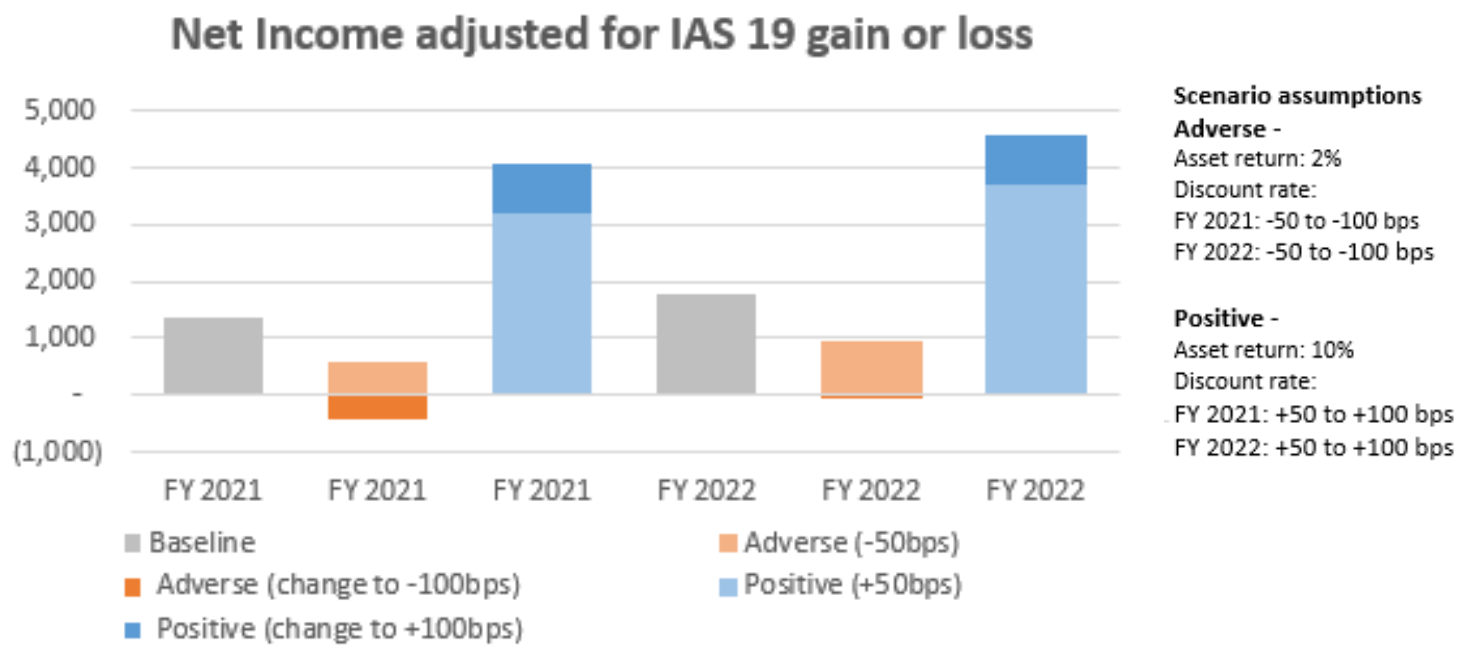

${ }^{1}$ The scenarios are illustrative in nature and analyze the sensitivity of the baseline to changes in the discount rate and asset returns, while keeping all other key financial and demographic assumptions constant. 


\section{Annex III. Investment Account (IA) Performance Scenarios}

The two IA subaccounts have distinct investment objectives and pursue different strategies accordingly. This annex illustrates the range of expected investment returns based on different market scenarios. ${ }^{7}$

\section{Fixed-Income Subaccount (FI)}

The FI investment strategy aims to achieve returns in excess of the 3-month SDR interest rate over a three- to four-year horizon. The portfolio is invested in highly-rated liquid fixed-income instruments across two tranches: a short duration actively-managed tranche and a longer duration passively-managed tranche. The current portfolio duration is approximately 1.5 years.

Staff analysis illustrates that average FI returns are somewhat uncertain. Since last year, SDR government bond yields have declined by around 75 basis points (bp) on average, with longer maturity yields close to historic lows causing the yield curve to invert. The low levels of government bond yields is expected to translate into lower coupon income over time and less protection for the $\mathrm{Fl}$ against rising yields. Staff's analysis uses two yield curve scenarios (Figure A3.1): (i) yields remain unchanged from current levels; and (ii) yields move in line with market implied forward rates.

- Under the forward scenario, FI returns are projected to be higher than the 3-month SDR interest rate over a 5-year horizon (Figure A3.2). If rates move in line with the forwards scenario,

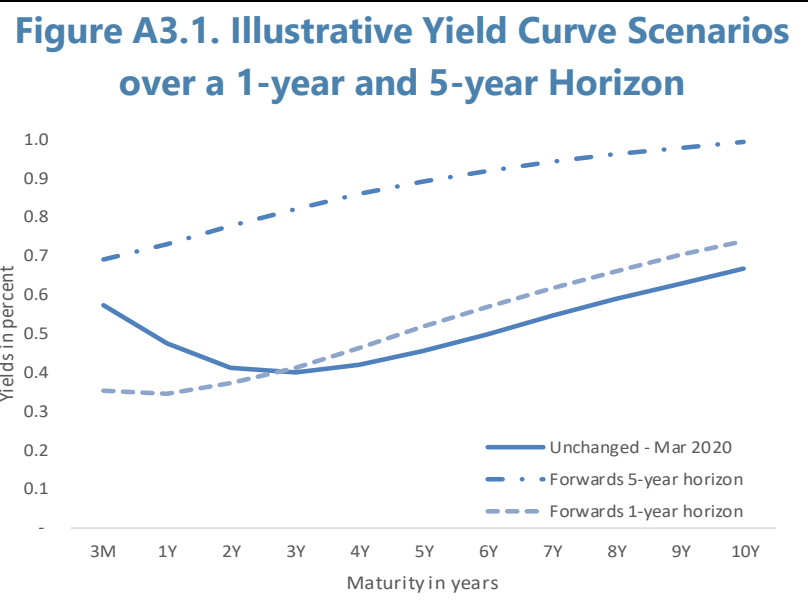

Source: Staff calculations based market conditions at end-February 2020. excess returns over the 3-month SDR rate would be around $12 \mathrm{bp}$. However, under the scenario that yields remain unchanged and the curve remains inverted, excess returns relative to the 3-month SDR rate would be negative.

- Risk return scenarios over a one-year horizon suggest the downside risks remain moderate, however, lower yield levels provide less protection against rising interest rates (Figure A3.3). Annual investment income from the FI is expected to fall within the range of SDR 5 million to SDR 155 million. ${ }^{2}$ Under the adverse scenario that yields rise sharply by around $55 \mathrm{bp}$ from the current levels, the 1-year return would be close to zero. If yields rise beyond that level the Fl is likely to record a negative return. The estimated worst-case loss would be

\footnotetext{
${ }^{1}$ A stochastic simulation model is used to derive a distribution of expected return projections from which the ex-ante risk statistics are measured. The range of possible risk and return outcomes for the IA will vary depending on the assumptions made regarding capital market returns and the future evolution of yields over the projection horizon.

2 Estimated based on a portfolio size of SDR 16.7 billion and one standard deviation around the average projected return under the unchanged yields and forwards scenario.
} 
about -0.9 percent (proxied by the 95 percent conditional value at risk ( $\mathrm{CVaR})$ ), equivalent to an SDR 150 million loss.

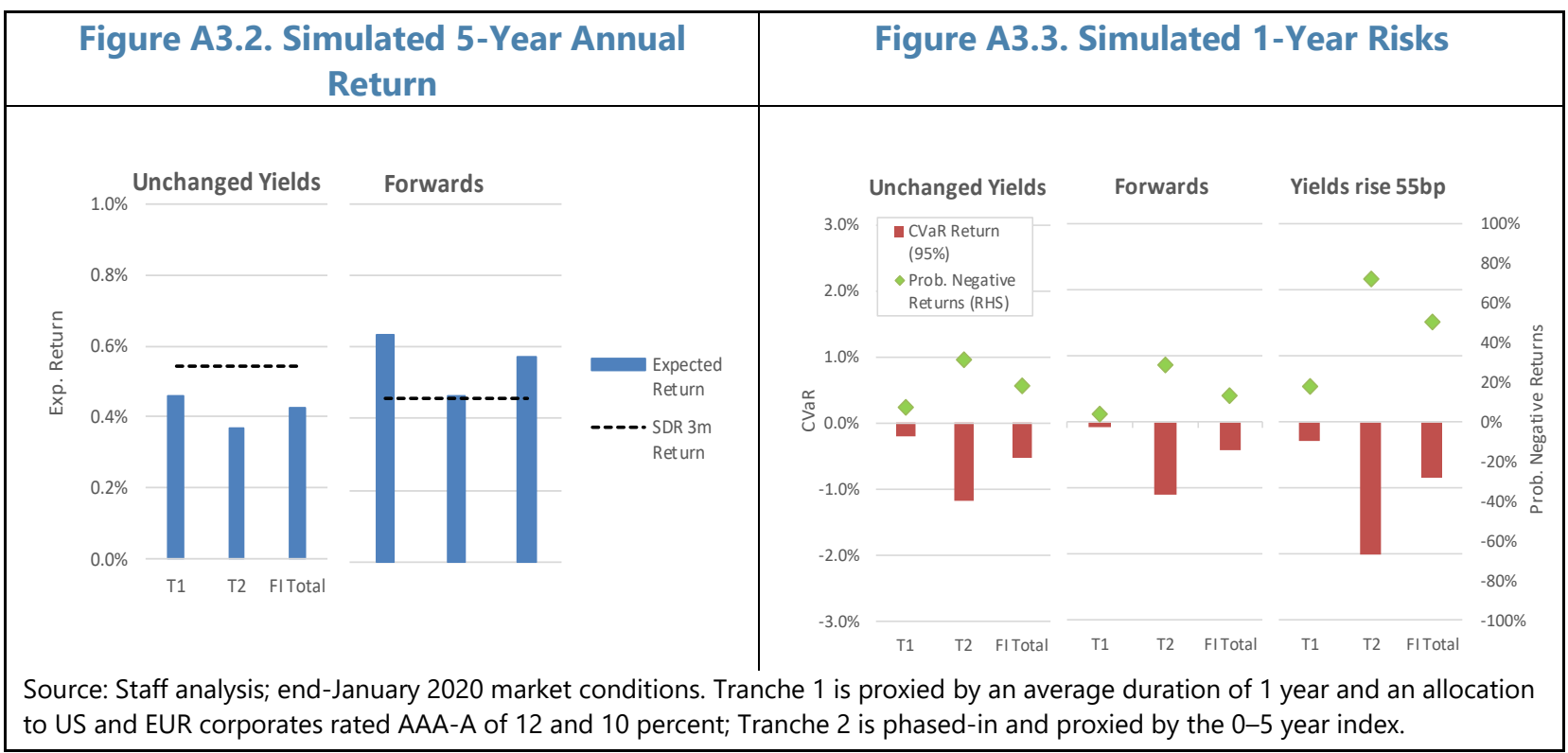

\section{Endowment Subaccount (EA)}

The investment objective of the EA is to generate a long-term real rate of return of $\mathbf{3}$ percent in US dollar terms. At least 90 percent of the EA is invested passively following a Strategic Asset Allocation (SAA) with a 60/40 percent split between global fixed-income and equity (Figure A4.4.a). ${ }^{3}$ The diverse range of assets in the SAA increases the probability of meeting the EA's return target over the long run at the expense of higher volatility of short-term returns, especially compared to the FI. The EA carries higher interest rate, currency and credit risks given its fixed-income assets duration of around 6 years and allocations to global equities, REITs, emerging market and corporate bonds.

The 3 percent real return target is likely to remain challenging to achieve in the medium term (Figure A4.4.b). Staff's forward-looking simulations based on the central market scenario indicate that it is likely the EA will underperform its 3 percent real return target as global yields have declined to historical lows and equity valuations are elevated. Average expected nominal returns in U.S. dollars are between 3.3 percent and 4.4 percent (approximately 1.3 and 2.5 percent in real terms) over a 5- and 15-year horizon respectively. In addition, the estimated worst-case annual loss (based on (VaR) is around 12 percent, equivalent to 990 million in U.S. dollar terms or 720 million in SDR terms.

\footnotetext{
${ }^{3}$ The actively managed portion is initially only 5 percent and managed in the same asset classes as of the passive but with wide deviation bands.
} 


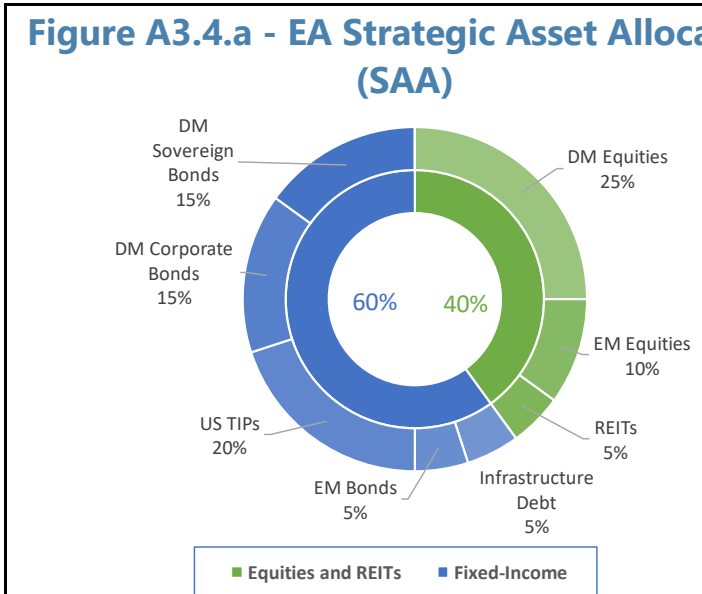

Figure A3.4.b - Simulated Annual Return and Risk for the EA (in U.S. dollar terms)

\begin{tabular}{lccc}
\hline \multicolumn{1}{c}{ Horizon } & $\begin{array}{c}\text { Medium-term } \\
\text { (5-year) }\end{array}$ & $\begin{array}{c}\text { Long-term } \\
(15 \text {-year })\end{array}$ \\
\hline Avg. Expected Nominal Return & $\mathbf{3 . 3 \%}$ & $4.4 \%$ \\
Standard Deviation & $8.3 \%$ & $8.3 \%$ \\
Reward-to-risk Ratio & 0.40 & 0.53 \\
VaR Return (95\%) & $-9.8 \%$ & $-8.7 \%$ \\
CVaR Return (95\%) & & $-12.5 \%$ & $-11.5 \%$ \\
\hline & $3 \%$ Real & $68.4 \%$ & $65.2 \%$ \\
$\quad$ Probability of & 2\% Real & $60.0 \%$ & $47.4 \%$ \\
Underperforming Real & 1\% Real & $49.4 \%$ & $30.0 \%$ \\
$\quad$ Return Target & 0\% Real & $39.6 \%$ & $14.6 \%$ \\
\hline Memo. Item & US Inflation & $2.0 \%$ & $2.0 \%$ \\
\hline
\end{tabular}

Source: Staff calculations based on market conditions as of end-January 2020. 


\section{Annex IV. Assumptions Underlying the Income Projections}

\begin{tabular}{|c|c|c|c|c|}
\hline \multicolumn{5}{|c|}{$\begin{array}{l}\text { Assumptions Underlying the Income Projections } \\
\text { (in billions of SDRs, unless otherwise stated) }\end{array}$} \\
\hline & \multicolumn{4}{|l|}{ Actual } \\
\hline & through & FY & FY & FY \\
\hline & Feb. 2020 & 2020 & 2021 & 2022 \\
\hline \multicolumn{5}{|l|}{ Regular Facilities: } \\
\hline 1. Purchases (excl. reserve tranche purchases) & 8.3 & 28.1 & 11.8 & 3.3 \\
\hline 2. Repurchases & 6.1 & 6.9 & 3.2 & 10.7 \\
\hline 3. Average balances subject to charges & 66.6 & 67.3 & 92.6 & 91.0 \\
\hline 4. Average SDR holdings & 22.1 & 22.1 & 22.7 & 23.6 \\
\hline 5. Average remunerated positions & 71.4 & 72.5 & 100.1 & 101.4 \\
\hline 6. Average investment account assets-Fixed-Income subaccount & 16.6 & 16.6 & 16.5 & 17.0 \\
\hline 7. Average investment account assets-Endowment subaccount & 5.6 & 5.6 & 5.7 & 5.8 \\
\hline \multirow[t]{2}{*}{ 8. Average borrowings and issued notes } & 11.6 & 11.1 & 8.4 & 6.4 \\
\hline & \multicolumn{4}{|c|}{ (In percent) } \\
\hline Return on investments-Fixed-Income subaccount ${ }^{1}$ & 1.54 & 1.81 & 0.28 & 0.57 \\
\hline Return on investments-Endowment subaccount ${ }^{1,2}$ & 4.47 & 3.03 & 3.30 & 2.57 \\
\hline \multicolumn{5}{|l|}{ Average interest rates: } \\
\hline SDR interest rate and basic rate of remuneration & 0.9 & 0.8 & 0.1 & 0.2 \\
\hline Basic rate of charge & 1.9 & 1.8 & 1.1 & 1.2 \\
\hline Margin on the rate of charge & 1.0 & 1.0 & 1.0 & 1.0 \\
\hline
\end{tabular}




\section{Annex V. Consolidated Medium-Term Income and Expenses}

\begin{tabular}{|c|c|c|c|c|c|c|c|c|c|c|}
\hline \multicolumn{11}{|c|}{ Consolidated Income and Expenses, FY 2020-30 Baseline Scenario ${ }^{1}$} \\
\hline & & \multirow[b]{4}{*}{ FY20 } & \multirow[b]{4}{*}{$\mathrm{FY} 21$} & \multirow[b]{4}{*}{ FY22 } & \multirow[b]{4}{*}{ FY23 } & \multirow[b]{4}{*}{ FY24 } & \multirow[b]{4}{*}{$\mathrm{FY} 25$} & \multicolumn{3}{|c|}{ Low-lending environment } \\
\hline & & & & & & & & \multicolumn{3}{|c|}{ Scenario A Scenario B } \\
\hline & & & & & & & & \multicolumn{3}{|c|}{$\begin{array}{lr}\text { SDRi } 2 \% & \text { SDRi } 1 \% \\
\text { P/out }=1.5 \% & \text { P/out }=1 \%\end{array}$} \\
\hline & & & & & & & & FY26 & FY30 & $\mathrm{FY} 30$ \\
\hline & & \multicolumn{9}{|c|}{ (in SDR millions) } \\
\hline A. & Operational income & 2,350 & 2,145 & 2,592 & 1,924 & 1,188 & 836 & 613 & 881 & 652 \\
\hline & Lending income & 1,942 & 1,968 & 2,354 & 1,631 & 883 & 500 & 275 & 247 & 247 \\
\hline & Margin for the rate of charge & 673 & 926 & 910 & 771 & 530 & 305 & 180 & 200 & 200 \\
\hline & Service charge & 140 & 59 & 16 & 5 & 1 & 0 & 0 & 23 & 23 \\
\hline & Commitment fees & 373 & 40 & 285 & 0 & 0 & 0 & 0 & 24 & 24 \\
\hline & Surcharges & 756 & 943 & 1,143 & 855 & 352 & 195 & 95 & 0 & 0 \\
\hline & Investment income & 298 & 103 & 154 & 200 & 212 & 235 & 236 & 449 & 274 \\
\hline & Fixed-Income Subaccount 1/ & 298 & 46 & 96 & 141 & 152 & 174 & 174 & 348 & 209 \\
\hline & Gold endowment pay-out 2/ & 0 & 57 & 58 & 59 & 60 & 61 & 62 & 101 & 65 \\
\hline & Interest free resources 3/ & 45 & 7 & 16 & 23 & 22 & 29 & 28 & 108 & 54 \\
\hline & SCA- 1 and other & 45 & 7 & 16 & 23 & 22 & 29 & 28 & 108 & 54 \\
\hline & Reimbursements & 65 & 67 & 68 & 70 & 71 & 72 & 74 & 77 & 77 \\
\hline & SDR Department & 3 & 3 & 3 & 3 & 3 & 3 & 3 & 3 & 3 \\
\hline & PRG Trust & 62 & 64 & 65 & 67 & 68 & 69 & 71 & 74 & 74 \\
\hline & Expenses & 902 & 905 & 929 & 951 & 971 & 988 & 1,004 & 1,040 & 1,040 \\
\hline & Net administrative budget & 839 & 847 & 866 & 881 & 895 & 914 & 930 & 971 & 971 \\
\hline & Capital budget items expensed & 18 & 9 & 9 & 9 & 10 & 10 & 10 & 11 & 11 \\
\hline & Depreciation & 45 & 49 & 54 & 61 & 66 & 64 & 64 & 58 & 58 \\
\hline & Net operational income (loss) (A-B) & 1,448 & 1,240 & 1,663 & 973 & 217 & -152 & -391 & -159 & -388 \\
\hline D. & Pension and other benefits related (IAS 19) loss & $-2,252$ & 0 & 0 & 0 & 0 & 0 & 0 & 0 & 0 \\
\hline \multicolumn{11}{|c|}{ Net operational income (loss) after pension-related } \\
\hline & (IAS 19) adjustment (C-D) & -804 & 1,240 & 1,663 & 973 & 217 & -152 & -391 & -159 & -388 \\
\hline & Endowment (Gold Profits) Subaccount & 167 & 130 & 91 & 135 & 95 & 208 & 170 & 159 & 0 \\
\hline & Net income (loss) & -637 & 1,370 & 1,754 & 1,108 & 312 & 56 & -221 & 0 & -388 \\
\hline \multicolumn{11}{|c|}{ (in US\$ millions) } \\
\hline \multirow[t]{5}{*}{ E. } & Operational income & 3,242 & 3,003 & 3,656 & 2,711 & 1,687 & 1,193 & 875 & 1,320 & 977 \\
\hline & Lending income (including Surcharges) & 2,680 & 2,755 & 3,320 & 2,299 & 1,254 & 714 & 393 & 370 & 370 \\
\hline & Investment income & 411 & 144 & 217 & 281 & 301 & 336 & 338 & 674 & 411 \\
\hline & Interest free resources & 62 & 10 & 23 & 33 & 31 & 40 & 39 & 161 & 81 \\
\hline & Reimbursements & 89 & 94 & 96 & 98 & 101 & 103 & 105 & 115 & 115 \\
\hline & Expenses & 1,244 & 1,267 & 1,309 & 1,342 & 1,379 & 1,412 & 1,436 & 1,559 & 1,559 \\
\hline & Net administrative budget & 1,158 & 1,186 & 1,221 & 1,243 & 1,271 & 1,307 & 1,330 & 1,457 & 1,457 \\
\hline & Capital budget items expensed & 24 & 13 & 12 & 13 & 15 & 14 & 14 & 16 & 16 \\
\hline & Depreciation & 62 & 68 & 76 & 86 & 93 & 91 & 92 & 86 & 86 \\
\hline & Net operational income (loss) (E-F) & 1,998 & 1,736 & 2,347 & 1,369 & 308 & -219 & -561 & -239 & -582 \\
\hline \multicolumn{11}{|c|}{ Memorandum Items: } \\
\hline & Fund credit (average stock, SDR billions) & 67.3 & 92.6 & 91.0 & 77.1 & 53.0 & 30.5 & 18.0 & 20.0 & 20.0 \\
\hline & SDR interest rate (in percent) & 0.8 & 0.1 & 0.2 & 0.3 & 0.3 & 0.4 & 0.4 & 2.0 & 1.0 \\
\hline & US\$/SDR exchange rate & 1.38 & 1.40 & 1.41 & 1.41 & 1.42 & 1.43 & 1.43 & 1.50 & 1.50 \\
\hline & Precautionary balances (end of period, SDR billions) & 16.7 & 18.0 & 19.6 & 20.6 & 20.8 & 20.7 & 20.3 & 15.0 & 15.0 \\
\hline \multicolumn{11}{|c|}{$\begin{array}{l}{ }^{1} \text { The current medium-term projections are conservative and assume that a premium of } 50 \text { basis points over the SDR rate is } \\
\text { attained in the longer run. } \\
{ }^{2} \text { The baseline projections assume a } 1 \text { percent payout from the gold endowment commencing in FY 2021. The illustrative scenarios } \\
\text { for FY } 2030 \text { show a continued payout of } 1 \text { percent in a low investment return environment (Scenario B); and a higher payout of } 1.5 \\
\text { percent in a high investment return environment (Scenario A). } \\
{ }^{3} \text { Interest free resources reduce the Fund's costs and therefore provide implicit returns. Since the Fund invests its reserves in the IA } \\
\text { to earn a higher return, the interest free resources retained in the GRA are mainly attributable to the SCA-1, unremunerated } \\
\text { reserve tranche positions not represented by gold holdings, and GRA income for the year not transferred to the IA. These } \\
\text { resources reduce members' reserve tranche positions and the Fund's remuneration expense, or increase interest income if reflected } \\
\text { in SDR holdings of the GRA, resulting in implicit income for the Fund. }\end{array}$} \\
\hline
\end{tabular}




\section{Annex VI. Reconciliation of Projected Income and Expenses- FY 2020}

\section{Linking the Analytical Presentation with the Fund's Income Statement}

The purpose of this Annex is to prepare a reconciliation between the analytical framework presented in Table A6.1 of this paper and the traditional format used to prepare the Fund's income statement under IFRS. ${ }^{1}$ The formulation of the Fund's income and expense flow results in the same projected net income position. However, the analytical framework is preferred in discussing the income position as it succinctly captures the main variables that drive the Fund's income position. To this end, the presentation focuses on the net contribution made by the Fund's income-earning assets.

The starting point to move from the traditional format in the Fund's financial statements to the analytical framework in the paper is to net the financing costs (remuneration and interest on borrowings) against the income generated from Fund credit and the GRA's SDR holdings. This provides the income from the margin and interest free resources by eliminating the flows from the SDR interest rate between the debtor and creditor members of the Fund. Thereafter, the main adjustments involve re-arranging the various line items on the Fund's IFRS financial statements to the analytical framework. This includes:

- Reallocation of surcharges from interest and charges;

- Reallocation of income from the Endowment Subaccount from total investment income since this amount is retained in the investment account; and

- Separation of the reimbursements and the pension related (IAS 19) gains/(losses) from administrative expenses.

Table A6.1 below highlights this reconciliation process.

\footnotetext{
1 The Annex is prepared in response to requests to simplify and explain the process of reconciling various aspects of the Fund's financial structure.
} 


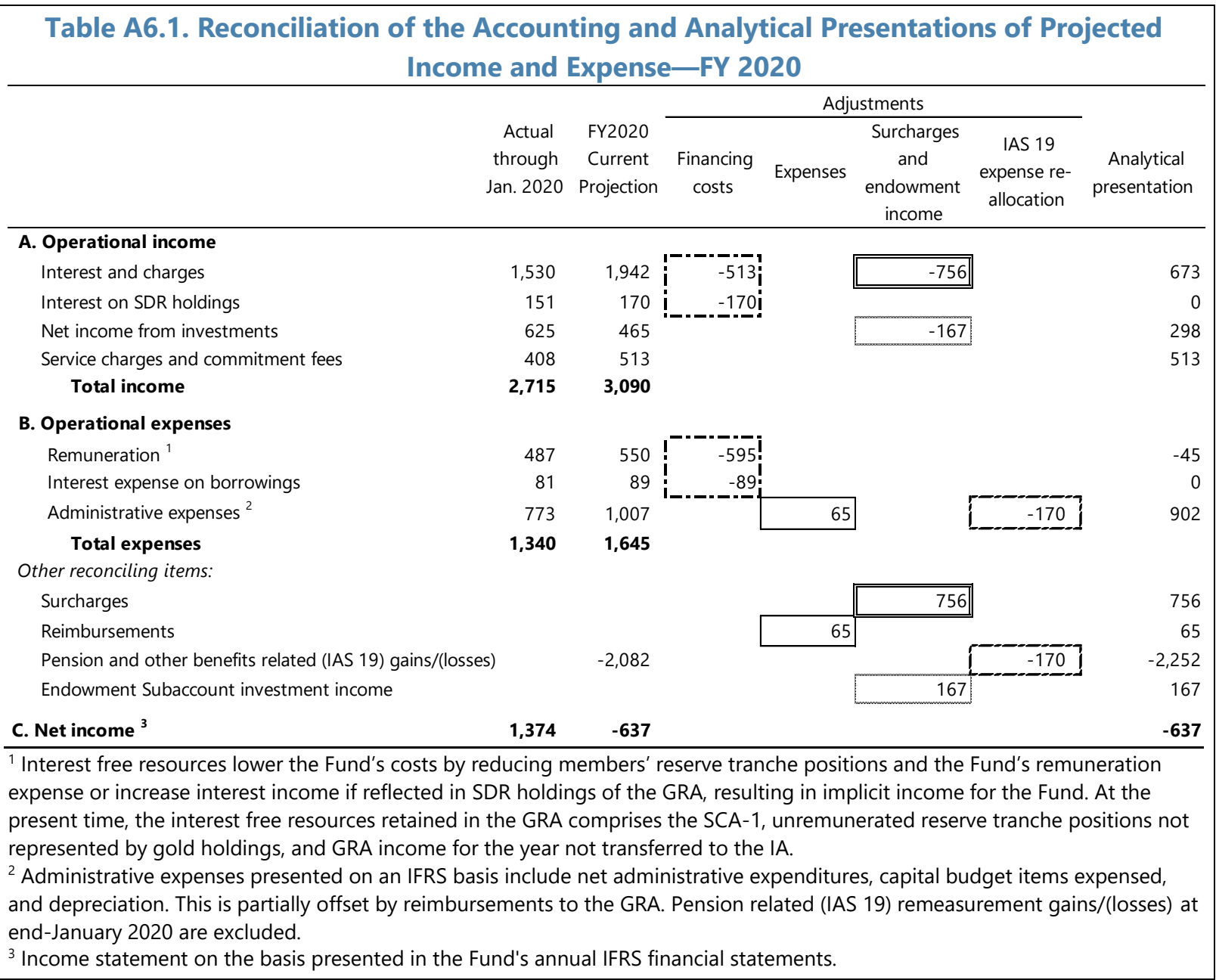

\section{CInternational Monetary Fund. Not for Redistribution}




\section{INTERNATIONAL MONETARY FUND}

April 21, 2020

REVIEW OF THE FUND'S INCOME POSITION FOR FY 2020

AND FY 2021-2022-SUPPLEMENTARY INFORMATION

\section{EXECUTIVE SUMMARY}

This supplement updates the Review of the Fund's Income Position for FY 2020 and FY 2021-2022 (4/13/20) for the latest information that has become available since the circulation of that paper to the Executive Board on April 13, 2020. The updates reflect developments in March and early April and do not alter the main conclusions of the paper. 
Approved By Andrew Tweedie
Prepared by the Finance Department in consultation with the Legal, Secretary's, and Strategy, Policy, \& Review Departments, the Office of Budget and Planning, and the Office of Risk Management.

\section{CONTENTS}

INTRODUCTION

REVIEW OF THE FY 2020 INCOME POSITION

FY 2021-2022 INCOME OUTLOOK______________________________________

A. Summary of Key Risks _____ $\underline{6}$

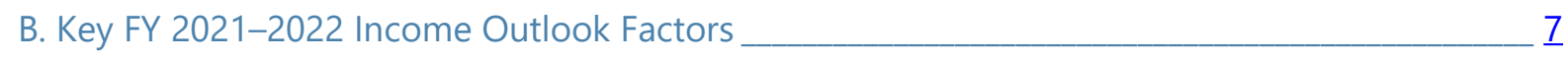

C. Review of the Margin for the Rate of Charge ______ $\underline{9}$

\section{FIGURES}

1. Projected Precautionary Balances Accumulation $\underline{9}$

2. Projected Non-Lending Operational Income and Non-Lending Expenses 11

\section{TABLES}

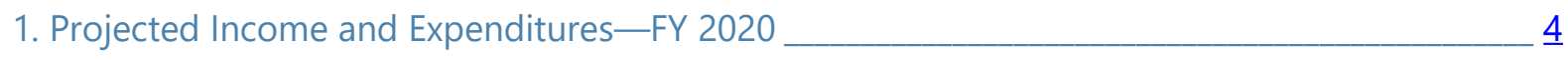

2. Projected Income Sources and Uses_FY 2020-2022______

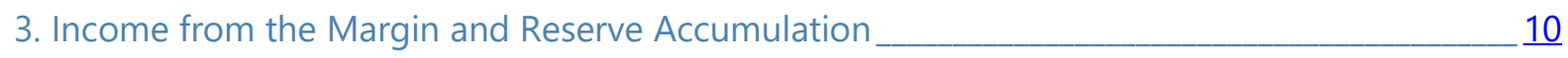

4. Burden Sharing Adjustment Rates _________ 12

\section{ANNEXES}

I. Investment Account (IA) Performance 13

II. Assumptions Underlying the Income Projections $\underline{16}$

III. Consolidated Medium-Term Income and Expenses 


\section{INTRODUCTION}

1. The supplement updates the projections of the Fund's income position for FY 2020 and FY 2021-2022 in the staff paper issued to the Executive Board on April 13. ${ }^{1}$ The update incorporates additional information on developments through early April. The lending income projections for FY 2020 and FY 2021-2022 are broadly unchanged from the staff paper. ${ }^{2}$ However, a net income loss of about SDR 1 billion is now projected for FY 2020 in the GRA, compared with SDR 0.8 billion previously, mainly reflecting a higher estimated pension-related (IAS 19) loss. The endowment subaccount is also now projected to record a modest loss. The income projections for FY 2021-22 are broadly unchanged.

\section{Uncertainties around the intensity and duration of the Covid-19 crisis will continue to} impact the near term income outlook. Despite the close proximity of the updated projections to year end, the final income outlook for FY 2020 remains somewhat uncertain as described below. The outlook for FY 2021-22 is highly sensitive to the future path for interest rates and new demand for Fund resources, which could expand well beyond the updated projections in this supplement.

3. The supplement is structured as follows: The first section updates the FY 2020 income position for the main changes since the earlier projections, and the second section updates the income projections for the period FY 2021-22. Key tables, charts, and annexes have also been updated. An annex on the Investment Account (IA) Performance provides an update on the performance of the two IA subaccounts.

\section{REVIEW OF THE FY 2020 INCOME POSITION}

\section{A net loss of about SDR 1 billion is now projected for the GRA in FY 2020 compared} with SDR 0.8 billion in the staff paper. ${ }^{3}$ The main factors contributing to the higher loss are discussed below.

Investment Income-Fixed-Income Subaccount (FI): Investment income from the subaccount is now projected at SDR 253 million compared with SDR 298 million in the staff paper. The updated projection reflects mainly the slightly negative portfolio returns in March due to a widening of credit

\footnotetext{
${ }^{1}$ Review of the Fund's Income Position for FY 2020 and FY 2021-2022 (04/13/20).

2 Emergency financing, including augmentations and drawings under current precautionary arrangements, to member countries facing immediate financing needs is projected to be about SDR 32 billion, based on updated data through April 14 (compared with about SDR 26 billion as of March 27 in the staff paper).

${ }^{3}$ The net loss in the GRA in FY 2020 depletes the special reserve, slowing down the overall pace of reserve accumulation and the build-up of the Fund's precautionary balances (see Figure 1 below). It also leads to a suspension of the transfer of currencies from the GRA to the Fixed-Income subaccount, thereby lowering future contributions from the IA.
} 
spreads and mark-to-market losses on short-duration credit assets (Annex I). As before, this projection remains uncertain given recent heightened bond market volatility.

Table 1. Projected Income and Expenditures_FY 2020

(in millions of SDRs)

A. Operational income

Lending income

Margin for the rate of charge

Service charges

Commitment fees

Surcharges

Investment income

Fixed-Income Subaccount (reserves)

Endowment Subaccount payout ${ }^{2}$

Interest free resources ${ }^{3}$

SCA- 1 and other

Reimbursements

SDR Department

PRG Trust

B. Expenses

Net administrative expenditures

Capital budget items expensed

Depreciation

C. Net operational income (A-B)

Pension and other benefits related (IAS 19) losses

D. Net operational income/(loss) after IAS 19 adjustment

Endowment subaccount investment income ${ }^{2}$

Net income/(loss) position

Memorandum Items:

Fund credit (average stock, SDR billions)

SDR interest rate (average, in percent)

US\$/SDR exchange rate (average)

Precautionary balances (end of period, SDR billions)

\begin{tabular}{|c|c|c|}
\hline \multicolumn{3}{|c|}{ FY2020 } \\
\hline Initial & $E B S / 20 / 58$ & Supplement \\
\hline Projections ${ }^{1}$ & Projections & Projections \\
\hline 2,418 & 2,350 & 2,251 \\
\hline 2,068 & 1,942 & 1,889 \\
\hline 735 & 673 & 667 \\
\hline 86 & 140 & 97 \\
\hline 357 & 373 & 373 \\
\hline 890 & 756 & 752 \\
\hline 208 & 298 & 253 \\
\hline 208 & 298 & 253 \\
\hline 0 & 0 & 0 \\
\hline 74 & 45 & 44 \\
\hline 74 & 45 & 44 \\
\hline 68 & 65 & 65 \\
\hline 3 & 3 & 3 \\
\hline 65 & 62 & 62 \\
\hline 888 & 902 & 895 \\
\hline 821 & 839 & 832 \\
\hline 21 & 18 & 18 \\
\hline 46 & 45 & 45 \\
\hline 1,530 & 1,448 & 1,356 \\
\hline 0 & $-2,252$ & $-2,375$ \\
\hline 1,530 & -804 & $-1,019$ \\
\hline 156 & 167 & -126 \\
\hline 1,686 & -637 & $-1,145$ \\
\hline 73.5 & 67.3 & 66.7 \\
\hline 1.2 & 0.8 & 0.8 \\
\hline 1.41 & 1.38 & 1.38 \\
\hline 19.2 & 16.7 & 16.5 \\
\hline
\end{tabular}

Source: Finance Department and Office of Budget and Planning

${ }^{1}$ Review of the Fund's Income Position for FY 2019 and FY 2020 (03/19/19).

${ }^{2}$ Consistent with the EA payout policy framework endorsed by the Executive Board in April 2018, the initiation of payouts is assumed to be delayed (until at least FY 2021).

${ }^{3}$ Interest free resources reduce the Fund's costs and therefore provide implicit returns. Since the Fund invests its reserves in the IA to earn a higher return, the interest free resources retained in the GRA are mainly attributable to the SCA-1, unremunerated reserve tranche positions not represented by gold holdings, and GRA income for the year not transferred to the IA. These resources reduce members' reserve tranche positions and the Fund's remuneration expense, or increase interest income if reflected in SDR holdings of the GRA, resulting in implicit income for the Fund. 
Pension-related (IAS 19) expense: The updated expense projected for the year is based on actual information to April 9, and is slightly higher than the estimate in the staff paper, reflecting mainly an increase in the net actuarial remeasurement losses to SDR 2,204 million compared with a projection of SDR 2,083 million in the staff paper (Text Table). The higher remeasurement loss reflects a significant worsening in expected returns on the plan assets, which more than offsets the positive impact of a higher discount rate compared with previous estimates. More specifically:

- The discount rate increased from a historically low rate of 2.71 percent ${ }^{4}$ to 2.97 percent, based on the latest estimate provided by the Fund's actuaries as of April 9, erasing one quarter of the losses estimated in the staff paper. However, the rate remains 89 basis points below the level at the start of the year and continues to have a significant impact on the projected pension-related (IAS 19) loss for the year.

- Asset performance has been very volatile during March and valuations reflect the large market declines recognized in the month offset partly by the slight recovery during early April. The remeasurement of plan assets is currently projected to be negative

SDR 857 million compared with negative SDR 206 million in the staff paper (see Text Table).

- Given ongoing financial market volatility, considerable uncertainties remain relating to the discount rate that will be used to measure the Fund's retirement plan obligations at April 30, 2020, and to the Text Table. Reconciliation of Pension-Related (IAS 19) Gains/(Losses) (in millions of SDRs)

\begin{tabular}{|c|c|c|}
\hline & \multicolumn{2}{|c|}{ Projected for FY 2020} \\
\hline & $\begin{array}{c}\text { Per Staff } \\
\text { Paper } \\
\text { (EBS/20/58) }\end{array}$ & $\begin{array}{c}\text { Per } \\
\text { Supplement }{ }^{1}\end{array}$ \\
\hline Accrual vs. Funding & -170 & -171 \\
\hline Pension cost accrual & -320 & -320 \\
\hline Service cost & -309 & -309 \\
\hline Interest expense on pension liability & -377 & -377 \\
\hline Expected income on pension asset ${ }^{2}$ & 366 & 366 \\
\hline Pension funding & 150 & 149 \\
\hline Remeasurement gains/(losses) & $-2,083$ & $-2,204$ \\
\hline Discount rate change & $-2,228$ & $-1,654$ \\
\hline 'Excess return' on assets ${ }^{2}$ & -206 & -857 \\
\hline Exchange rate translation & -24 & -46 \\
\hline Other ${ }^{3}$ & 376 & 353 \\
\hline Total IAS 19 gains/(losses) & $-2,252$ & $-2,375$ \\
\hline Discount rate - at end of period (in percent) & 2.71 & 2.97 \\
\hline
\end{tabular}

Source: Willis Towers Watson and IMF Finance Department

${ }^{1}$ The asset revaluations for the year are projected to end of the year and are based on actual portfolio performance to April 9, 2020 with estimates for the remainder of the year, and the April 9 discount rate is projected to the end of the year.

${ }^{2}$ Total income from plan assets comprises two components for financial reporting purposes: i) the expected income on plan assets calculated using the discount rate, and included in the pension cost and ii) a gain or loss included in remeasurement losses that is in 'excess' of this expected income.

${ }^{3} \mathrm{FY} 20$ : estimate of CCBR salary scale assumption adjustment. full year asset returns on the retirement plan.

Lending Income: FY 2020 lending income is projected to be SDR 1.9 billion, slightly below the estimate in the staff paper.

\footnotetext{
${ }^{4}$ As of end-February 2020.
} 
- The slight decline in lending income is attributable mainly to lower service charges as certain disbursements previously assumed to fall in FY 2020 will now be made after April 30.

- The revised estimate for emergency financing stands at about SDR 32 billion as of April 14, up from about SDR 26 billion as of March 27. More than half of the additional financing is expected to be disbursed in the next financial year and has a minimal impact on FY 2020 lending income.

Reimbursements: Expected to remain unchanged in FY 2020 in U.S. dollar terms.

Expenses: In line with the Supplement to the FY 2021-23 Medium-Term Budget Paper (04/21/20) the FY 2020 net administrative budget outturn has been revised from full utilization of US $\$ 1,158$ million to a US\$10 million, or SDR 7 million, underspend (Annex III).

Investment income-Endowment Subaccount (EA): Based on updated projections for FY 2020, the EA is expected to incur a loss in SDR terms of about SDR 126 million for the year compared with a gain of SDR 167 million estimated in the staff paper. This reflects the sharp sell-off in risk assets during March that more than offset the earlier strong performance in the EA. An equivalent amount would be reflected in the special account for IA retained earnings, reducing the cumulative retained earnings of the IA (all attributed to the EA) to about SDR 970 million. As indicated in the staff paper, the income projections for the EA remain subject to considerable uncertainty given the high degree of volatility across the asset classes in which the EA is invested.

\section{DISPOSITION DECISIONS}

No changes expected to the disposition decisions.

\section{FY 2021-2022 INCOME OUTLOOK}

\section{A. Summary of Key Risks}

5. Key risks to Fund income and finances associated with recent developments include large new lending arrangements, as well cancellations and changes in the timing of purchases under existing arrangements; fluctuations in the annual pension-related gain or loss as determined under IAS 19; and uncertainties around the global interest rate environment and U.S. dollar/SDR exchange rate path. The risk of cancellation or rephasing of purchases under existing arrangements is expected to be mitigated by members seeking additional sources of funding as the crisis unfolds. As discussed in the staff paper, changes in actuarial assumptions that impact the annual pension-related gain or loss under IAS 19 can be substantial and have a significant impact on overall Fund income and accumulation of precautionary balances. While the broadening of non-lending income sources under the Fund's new income model is helping mitigate income risk, the low interest rate environment is expected to diminish the contributions from investment income in the near term. 


\section{B. Key FY 2021-2022 Income Outlook Factors}

\section{The outlook for the Fund's net income in FY 2021-2022 has been updated for the} impact of changes in key assumptions, notably investment returns and lending income. The lending projections for FY 2021-2022 are expected to remain broadly unchanged from the staff paper, which already reflected most of the surge in demand for Fund resources in the form of emergency financing that is current in the pipeline. As explained in the staff paper, no projections are made for the pension-related (IAS19) gain or loss beyond FY 2020.5

\section{Based on current projections, the income outlook for FY 2021-2022, excluding the} impact of the pension-related gain or loss, is expected to remain strong. Overall net income is projected at about SDR 1.4 billion and SDR 1.8 billion for FY 2021 and FY 2022, respectively (Table 2), in line with the projections in the staff report.

Lending Income. The lending projections incorporated in the baseline have been updated based on more recent information on requests and inquiries for financing by member countries. Based on information available as of April 14, lending income is expected to increase slightly due mainly to higher service charges following the rephasing of certain disbursements to FY 2021. Margin income is projected to increase over the medium term following the addition of new RFI arrangements; this increase is fully offset by surcharge income being lower than the earlier estimate largely reflecting the cancellation/revision of two large arrangements by members previously subject to surcharges. ${ }^{6}$

Fixed-Income Subaccount. The SDR interest rate path in FY 2021-22 is projected to be slightly lower than in the staff paper resulting in a corresponding decrease in the investment income estimate for the subaccount. The rates in FY 2021-22 reflect lower overall bond yields across SDR markets after reaching historically low levels in March.

Endowment Subaccount. The slight drop in the estimated EA payout amount in FY 2021-22 reflects the lower net asset value now projected at end FY 2020.

Interest-free resources. The lower SDR interest rate in FY 2022 lowers implicit income from interest free resources.

Reimbursements and Expenses: Expected to remain largely unchanged in U.S. dollar terms.

\footnotetext{
${ }^{5}$ As indicated in the staff paper, given the degree of uncertainty, staff's view is that explaining the outcome of the pension-related (IAS 19) adjustment relative to a zero base is more coherent than doing so relative to a projected outcome based on hypothetical assumptions.

6 The access limit for RFIs is 100 percent of quota (see Enhancing the Emergency Financing Toolkit-Responding to the Covid-19 Pandemic (04/02/20)). A level-based surcharge of 200 basis points applies to outstanding amounts above 187.5 percent of quota. An additional time-based surcharge of 100 basis points applies to outstanding amounts above 187.5 percent of quota for more than 36 months (or 51 months for the EFF).
} 


\begin{tabular}{|c|c|c|c|c|c|c|}
\hline \multicolumn{7}{|c|}{$\begin{array}{l}\text { Table 2. Projected Income Sources and Uses-FY 2020-2022 } \\
\text { (in millions of SDRs) }\end{array}$} \\
\hline & \multicolumn{3}{|c|}{ EBS/20/58 Projection } & \multicolumn{3}{|c|}{ Supplement } \\
\hline & FY2020 & FY2021 & FY2022 & FY2020 & FY2021 & FY2022 \\
\hline A. Operational income & 2,350 & 2,145 & 2,592 & 2,251 & 2,220 & 2,571 \\
\hline Lending income & 1,942 & 1,968 & 2,354 & 1,889 & 2,039 & 2,369 \\
\hline Margin for the rate of charge & 673 & 926 & 910 & 667 & 961 & 951 \\
\hline Service charges & 140 & 59 & 16 & 97 & 125 & 13 \\
\hline Commitment fees & 373 & 40 & 285 & 373 & 40 & 285 \\
\hline Surcharges & 756 & 943 & 1,143 & 752 & 913 & 1,120 \\
\hline Investment income & 298 & 103 & 154 & 253 & 105 & 124 \\
\hline Fixed-Income subaccount (reserves) & 298 & 46 & 96 & 253 & 51 & 69 \\
\hline Endowment subaccount payout ${ }^{1}$ & 0 & 57 & 58 & 0 & 54 & 55 \\
\hline Interest free resources ${ }^{2}$ & 45 & 7 & 16 & 44 & 7 & 8 \\
\hline SCA- 1 and other & 45 & 7 & 16 & 44 & 7 & 8 \\
\hline Reimbursements ${ }^{3}$ & 65 & 67 & 68 & 65 & 69 & 70 \\
\hline SDR Department & 3 & 3 & 3 & 3 & 3 & 3 \\
\hline PRG Trust & 62 & 64 & 65 & 62 & 66 & 67 \\
\hline B. Expenses & 902 & 905 & 929 & 895 & 924 & 948 \\
\hline Net administrative expenditures & 839 & 847 & 866 & 832 & 866 & 885 \\
\hline Capital budget items expensed & 18 & 9 & 9 & 18 & 9 & 9 \\
\hline Depreciation & 45 & 49 & 54 & 45 & 49 & 54 \\
\hline C. Net operational income (A-B) & 1,448 & 1,240 & 1,663 & 1,356 & 1,296 & 1,623 \\
\hline Pension and other benefits related (IAS 19) losses ${ }^{4}$ & $-2,252$ & 0 & 0 & $-2,375$ & 0 & 0 \\
\hline \multicolumn{7}{|l|}{ D. Net operational income/(loss) after IAS 19} \\
\hline adjustment & -804 & 1,240 & 1,663 & $-1,019$ & 1,296 & 1,623 \\
\hline Endowment subaccount investment income & 167 & 130 & 91 & -126 & 116 & 122 \\
\hline Net income position & -637 & 1,370 & 1,754 & $-1,145$ & 1,412 & 1,745 \\
\hline \multicolumn{7}{|l|}{ Memorandum items: } \\
\hline Fund credit (average stock, SDR billions) & 67.3 & 92.6 & 91.0 & 66.7 & 96.1 & 95.1 \\
\hline SDR interest rate (average, in percent) & 0.8 & 0.1 & 0.2 & 0.8 & 0.1 & 0.1 \\
\hline US\$/SDR exchange rate (average) & 1.38 & 1.40 & 1.41 & 1.38 & 1.37 & 1.38 \\
\hline Precautionary balances (end of period, SDR billions) & 16.7 & 18.0 & 19.6 & 16.5 & 17.8 & 19.4 \\
\hline Source: Finance Department and Office of Budget and & & & & & & \\
\hline $\begin{array}{l}{ }^{1} \text { Consistent with the EA payout policy framework endorse } \\
\text { is assumed to be delayed (until at least FY 2021). } \\
{ }^{2} \text { Interest free resources reduce the Fund's costs and there } \\
\text { in the IA to earn a higher return, the interest free resource } \\
\text { unremunerated reserve tranche positions not represented } \\
\text { the IA. These resources reduce members' reserve tranche p } \\
\text { interest income if reflected in SDR holdings of the GRA, re } \\
{ }^{3} \text { No incremental costs are projected in managing the SDA } \\
{ }^{4} \text { See Annex II of Review of the Fund's Income Position for } \\
\text { sensitivity of the FY } 2021 \text { and FY } 2022 \text { projections to chan } \\
\text { asset returns, keeping other assumptions constant. }\end{array}$ & $\begin{array}{l}\text { y the Exec } \\
\text { e provide } \\
\text { tained in } \\
\text { yold holdin } \\
\text { ions and th } \\
\text { ing in imp } \\
\text { sources in } \\
020 \text { and } F \\
\text { in the key }\end{array}$ & $\begin{array}{l}\text { utive Boar } \\
\text { mplicit ret } \\
\text { he GRA ar } \\
\text { gs, and GR } \\
\text { e Fund's re } \\
\text { icit income } \\
\text { the CCR ar } \\
2021-20 \\
\text { actuarial a }\end{array}$ & $\begin{array}{l}\text { d in April } 2 \\
\text { urns. Since } \\
\text { e mainly at } \\
\text { A income f } \\
\text { muneratio } \\
\text { for the Fu } \\
\text { d PRG-HI } \\
22(4 / 13 / 2 \\
\text { Issumption }\end{array}$ & $\begin{array}{l}\text { 18, the init } \\
\text { he Fund in } \\
\text { ibutable tc } \\
\text { the year } r \\
\text { expense, c } \\
\text { d. } \\
\text { Trusts. } \\
\text { which illus } \\
\text { viz.; the d }\end{array}$ & $\begin{array}{l}\text { lation of } p \\
\text { vests its re } \\
\text { the SCA- } \\
\text { ot transfer } \\
r \text { increase }\end{array}$ & $\begin{array}{l}\text { ayouts } \\
\text { serves } \\
1, \\
\text { red to }\end{array}$ \\
\hline
\end{tabular}




\section{Review of the Margin for the Rate of Charge}

\section{Reserve Accumulation}

\section{Reserve accumulation in FY 2021 and FY 2022 is projected to be broadly in line with}

the staff paper. Table 3 updates the earlier estimates. Precautionary balances are now projected to decline to SDR 16.5 billion by end-FY 2020, lower than the SDR 16.7 billion estimated earlier mainly as a result of the increase in the projected pension-related (IAS 19) loss. However, reserve accumulation is projected to remain strong in the next few years, as credit outstanding is now projected to peak at SDR 96 billion in FY 2021 and to remain at high levels through at least FY 2023. As a result, the indicative medium-term target for precautionary balances of SDR 20 billion is still projected to be reached by FY 2023 (Figure 1). The outlook for subsequent years remains highly sensitive to potential new lending beyond the current surge in emergency financing. ${ }^{7}$

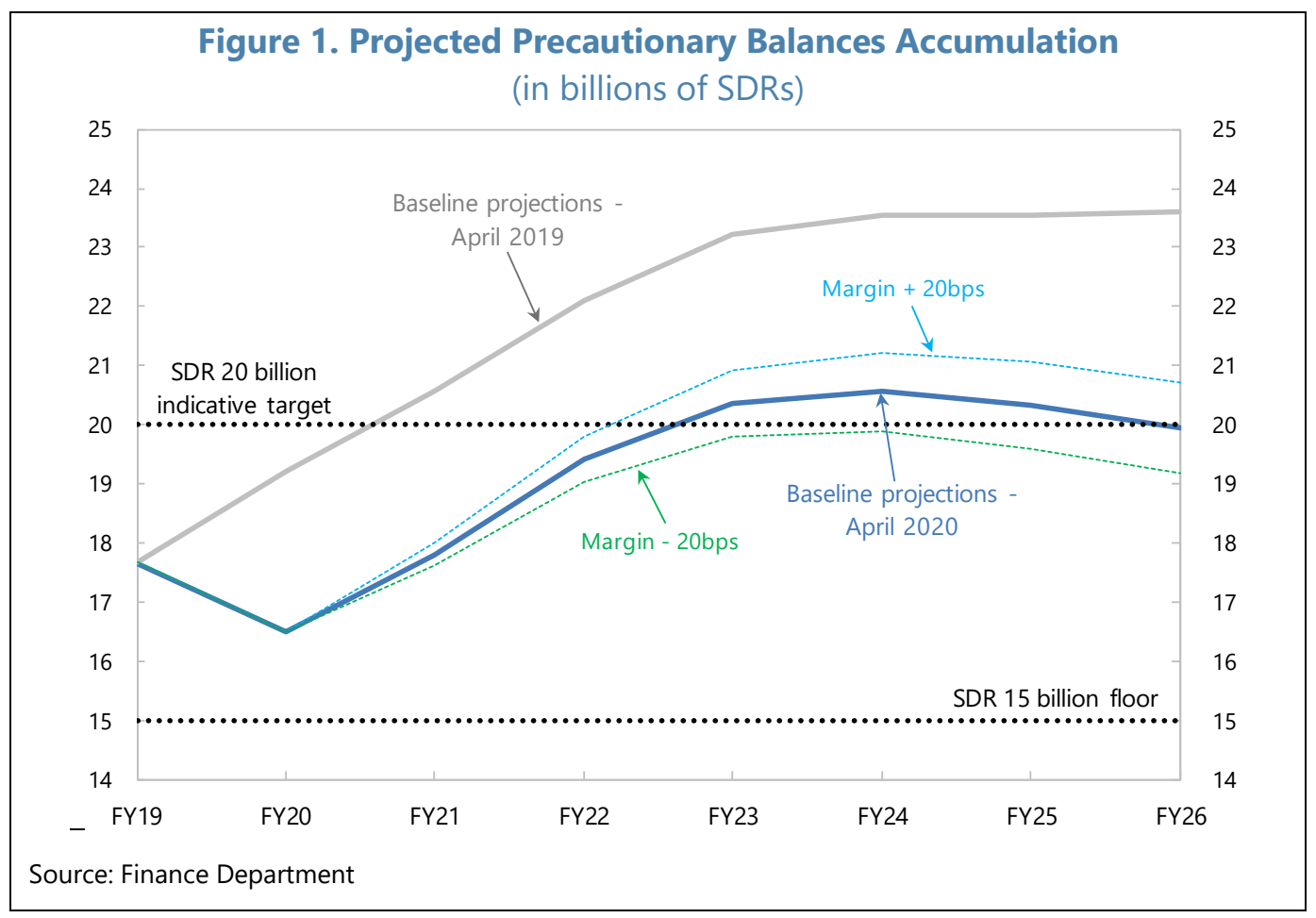

\footnotetext{
${ }^{7}$ The Board will have an opportunity for a fuller discussion of the adequacy of precautionary balances later in the year.
} 
Table 3. Income from the Margin and Reserve Accumulation ${ }^{1}$ (in millions of US Dollars, unless otherwise indicated)

\begin{tabular}{|c|c|c|c|c|c|c|}
\hline & \multicolumn{3}{|c|}{ EBS/20/58 Projection } & \multicolumn{3}{|c|}{ Supplement } \\
\hline & FY & $\mathrm{FY}$ & $\mathrm{FY}$ & $\mathrm{FY}$ & $\mathrm{FY}$ & FY \\
\hline & 2020 & 2021 & 2022 & 2020 & 2021 & 2022 \\
\hline A. Intermediation costs ${ }^{2}$ & 104 & 112 & 115 & 104 & 112 & 115 \\
\hline \multicolumn{7}{|l|}{ Less } \\
\hline B. Service charges & 193 & 83 & 23 & 134 & 171 & 18 \\
\hline C. Costs to be covered by income from margin (A-B) & -89 & 29 & 92 & -29 & -59 & 97 \\
\hline \multicolumn{7}{|l|}{ D. Income from margin ${ }^{3}$} \\
\hline 80 basis points & 743 & 1,038 & 1,026 & 737 & 1,053 & 1,050 \\
\hline 100 basis points & 928 & 1,297 & 1,283 & 921 & 1,316 & 1,312 \\
\hline 120 basis points & 1,114 & 1,556 & 1,540 & 1,105 & 1,579 & 1,575 \\
\hline E. Commitment fees ${ }^{4}$ & 515 & 56 & 402 & 515 & 55 & 393 \\
\hline E.1 FCL/PLL & 488 & 56 & 334 & 488 & 55 & 327 \\
\hline E.2 Other & 26 & 0 & 68 & 27 & 0 & 66 \\
\hline F. Surcharges ${ }^{5}$ & 1,043 & 1,320 & 1,612 & 1,038 & 1,251 & 1,546 \\
\hline \multicolumn{7}{|l|}{ G. Potential reserve accumulation ${ }^{6}(D+E+F-C)$} \\
\hline 80 basis points & 2,390 & 2,385 & 2,947 & 2,319 & 2,418 & 2,892 \\
\hline 100 basis points & 2,575 & 2,644 & 3,204 & 2,503 & 2,681 & 3,154 \\
\hline 120 basis points & 2,761 & 2,903 & 3,461 & 2,687 & 2,944 & 3,417 \\
\hline \multicolumn{7}{|l|}{ H. Potential reserve accumulation (as a percent) ${ }^{7}$} \\
\hline 80 basis points & $9.8 \%$ & $10.2 \%$ & $11.6 \%$ & $9.5 \%$ & $10.7 \%$ & $11.8 \%$ \\
\hline 100 basis points & $10.6 \%$ & $11.3 \%$ & $12.6 \%$ & $10.3 \%$ & $11.9 \%$ & $12.8 \%$ \\
\hline 120 basis points & $11.3 \%$ & $12.4 \%$ & $13.7 \%$ & $11.0 \%$ & $13.0 \%$ & $13.9 \%$ \\
\hline \multicolumn{7}{|l|}{ I. Actual reserve accumulation ${ }^{8}$} \\
\hline 80 basis points & $-1,295$ & 1,477 & 2,088 & $-1,590$ & 1,513 & 1,978 \\
\hline 100 basis points & $-1,110$ & 1,736 & 2,345 & $-1,406$ & 1,776 & 2,240 \\
\hline 120 basis points & -924 & 1,995 & 2,602 & $-1,222$ & 2,039 & 2,503 \\
\hline \multicolumn{7}{|l|}{ J. Actual reserve accumulation (as a percent) ${ }^{8}$} \\
\hline 80 basis points & $-5.3 \%$ & $6.3 \%$ & $8.2 \%$ & $-6.5 \%$ & $6.7 \%$ & $8.0 \%$ \\
\hline 100 basis points & $-4.6 \%$ & $7.4 \%$ & $9.3 \%$ & $-5.8 \%$ & $7.9 \%$ & $9.1 \%$ \\
\hline 120 basis points & $-3.8 \%$ & $8.5 \%$ & $10.3 \%$ & $-5.0 \%$ & $9.0 \%$ & $10.2 \%$ \\
\hline \multicolumn{7}{|c|}{ K. Precautionary balances at the end of FY (in SDR billions) ${ }^{9}$} \\
\hline 80 basis points & 16.6 & 17.8 & 19.4 & 16.4 & 17.6 & 19.2 \\
\hline 100 basis points & 16.7 & 18.0 & 19.6 & 16.5 & 17.8 & 19.4 \\
\hline 120 basis points & 16.9 & 18.2 & 19.8 & 16.6 & 18.0 & 19.6 \\
\hline \multicolumn{7}{|l|}{ Memorandum items } \\
\hline Average Fund credit outstanding (in SDR billions) & 67.3 & 92.6 & 91.0 & 66.7 & 96.1 & 95.1 \\
\hline Average exchange rate US\$/SDR & 1.38 & 1.40 & 1.41 & 1.38 & 1.37 & 1.38 \\
\hline
\end{tabular}

Source: Finance Department and Office of Budget and Planning

${ }^{1}$ For analytical purposes, surcharges and commitments fees are considered for reserve accumulation only.

${ }^{2}$ Costs related to the Fund's "generally available facilities."

${ }^{3}$ Derived by applying the margin against average Fund credit outstanding at the average US\$/SDR exchange rate.

${ }^{4}$ Includes commitment fees for expired or cancelled arrangements.

${ }^{5}$ Surcharges are projected on the basis of current quotas and surcharge thresholds.

${ }^{6}$ Potential reserve accumulation is derived by assuming other sources of income are sufficient to cover non-intermediation costs.

${ }^{7}$ Potential reserve accumulation as a percent of precautionary balances at the beginning of the financial year.

${ }^{8}$ Additions to or reductions in reserves based on net income or loss for the year (including actual and projected IAS 19 gains/(losses) up to FY 2020, and excludes retained Endowment Subaccount investment income).

${ }^{9}$ Precautionary balances include the Fund's reserves and SCA-1 balance less the gold endowment of SDR 4.4 billion. 


\section{Alignment of Fund Borrowing Costs with Market Conditions}

9. Staff's assessment of the alignment of the margin has not changed since end-February. The key indicator for this analysis (composite EMBI spread) is assessed on the basis of 5-year rolling medians, which remain broadly unchanged even with the inclusion of the recent spike in spreads in March and April.

\section{Exceptional Circumstances Clause}

10. Updated estimates suggest that the lending margin will continue to be set under the exceptional circumstances clause for the foreseeable future. Non-lending income (consisting of investment income and implicit income from interest free resources) is projected to be mostly lower over the medium term than the estimate in the staff paper, covering about 28 percent of the Fund's non-lending administrative expenses by FY 2026 (Figure 2).

Figure 2. Projected Non-Lending Operational Income and Non-Lending Expenses ${ }^{1}$ (in millions of SDR, percent)

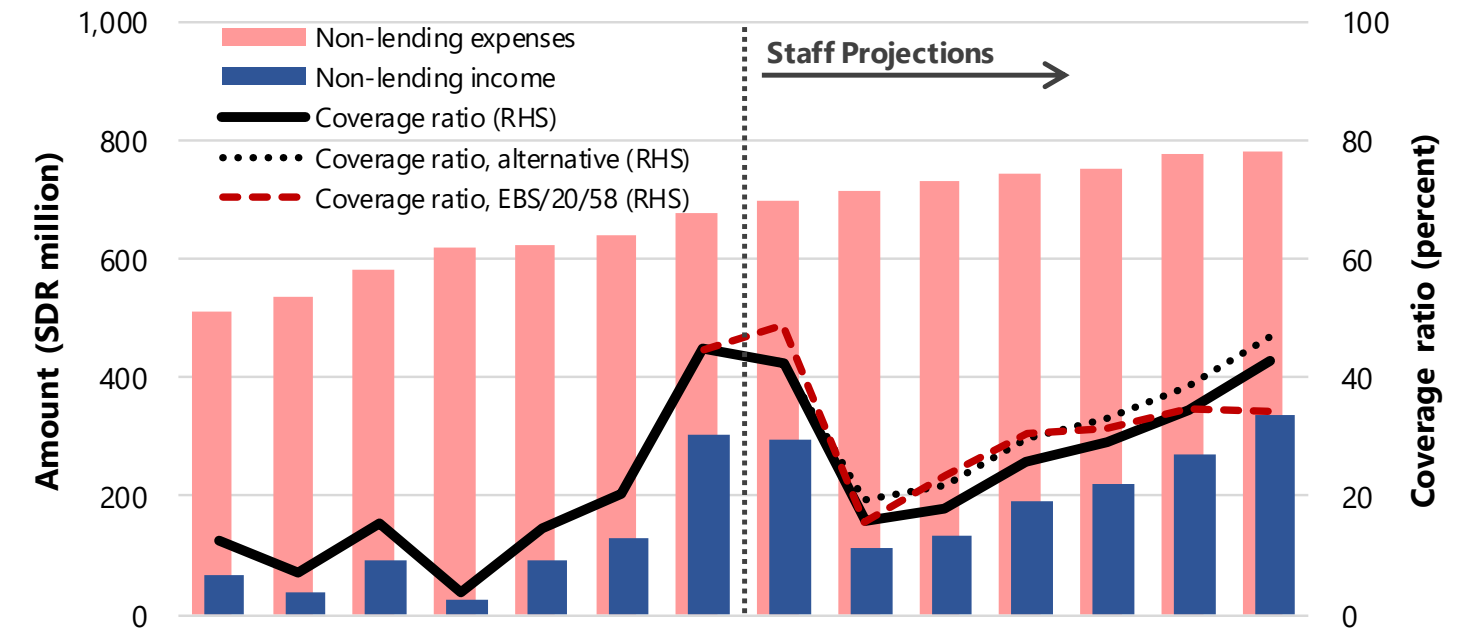

FY 13 FY 14 FY 15 FY 16 FY 17 FY 18 FY 19 FY 20 FY 21 FY 22 FY 23 FY 24 FY 25 FY 26

Source: Finance Department and Office of Budget and Planning

${ }^{1}$ Non-lending operational income comprises investment income and implicit income from interest free resources. Baseline projection assumes 1 percent payout from the Endowment Subaccount commencing in FY 2021. Alternative projection assumes 1.5 percent payout. Non-lending expenses are net administrative expenditures less intermediation costs related to generally available facilities, PRGT and SDR Department.

11. The projected burden sharing adjustment rates for FY 2020 are slightly lower than estimated in the staff paper (Table 4). The burden sharing adjustment rate is projected to be lower in Q4 FY 2020 following the recent clearance of Somalia's arrears, resulting in a lowering of the average rates projected for the year. 
Table 4. Burden Sharing Adjustment Rates

(in basis points, unless otherwise stated)

\begin{tabular}{|c|c|c|c|c|c|c|c|c|}
\hline & FY13 & FY14 & $\mathrm{FY} 15^{3}$ & FY16 & FY17 & FY18 & FY19 & FY20 \\
\hline & & & & & & & & Projected \\
\hline \multicolumn{9}{|l|}{ Rate of Remuneration ${ }^{1}$} \\
\hline Deferred charges & $--^{2}$ & $-{ }^{2}$ & 0.300 & 0.575 & 0.375 & 0.500 & 0.500 & 0.225 \\
\hline \multicolumn{9}{|l|}{ Rate of Charge ${ }^{1}$} \\
\hline Deferred charges & $--^{2}$ & $--^{2}$ & - & - & 0.150 & 0.500 & 0.500 & 0.275 \\
\hline Average SDR interest rate (in percent) & 0.09 & 0.09 & 0.061 & 0.051 & 0.187 & 0.678 & 1.037 & 0.763 \\
\hline Average basic rate of charge (in percent) & 1.09 & 1.09 & 1.061 & 1.051 & 1.187 & 1.678 & 2.037 & 1.763 \\
\hline
\end{tabular}




\section{Annex I. Investment Account (IA) Performance}

This annex provides a brief update on the performance of the two IA subaccounts. The portfolio will be reviewed during the year and include a discussion of policy, governance, and investment arrangements.

\section{Endowment Subaccount (EA)}

\section{Equity markets have fallen significantly since February, as the evolution of the} COVID-19 outbreak brought about a sharp deterioration in the global economic outlook. The magnitude of the decline in equity prices was not unusual by comparison with previous bear markets, but the speed of decline was unprecedented. Investors' flight to the safety of government bonds and central banks' policy responses have supported the performance of the fixed-income investments, while the returns on equity and real estate markets were all in negative territory for the IMF's current fiscal year to the end of March (Figure A1.1).

\begin{tabular}{|c|c|c|c|c|c|c|c|c|c|c|c|c|c|c|}
\hline & Figu & Ire A1 & 1.1. E & EA As & sset C & Class & Retu & urns b & by IM & F Fis & scal Y & lear & & \\
\hline & 2008 & 2009 & 2010 & 2011 & 2012 & 2013 & 2014 & 2015 & 2016 & 2017 & 2018 & 2019 & $2020 *$ & Average \\
\hline DM Sov. Bonds & 5.8 & 6.9 & 3.3 & 2.1 & 6.6 & 5.2 & 0.4 & 6.3 & 3.0 & 1.1 & 0.6 & 5.6 & 9.6 & 4.4 \\
\hline US TIPs 0-10Y & 10.2 & -0.7 & 8.1 & 7.1 & 6.5 & 2.5 & -3.6 & 0.8 & 1.2 & 1.6 & 0.0 & 3.2 & 3.9 & 4.7 \\
\hline EM Bonds $/ 1$ & 3.0 & -1.6 & 23.5 & 8.6 & 9.6 & 12.0 & -1.5 & -3.2 & $2-4.0$ & -3.9 & 10.7 & -0.3 & 0.7 & 7.0 \\
\hline Corporate Bonds $/ 2$ & 1.5 & -4.0 & 19.8 & 5.2 & 7.0 & 8.8 & 1.7 & 5.3 & 2.7 & 3.7 & 1.5 & 6.3 & 2.4 & 4.9 \\
\hline DM Equities & -2.7 & -38.6 & 39.8 & 19.7 & -4.4 & 17.4 & 17.6 & 7.8 & $\begin{array}{ll}3 & -3.4\end{array}$ & 15.7 & 74.0 & 6.3 & -14.4 & 7.4 \\
\hline EM Equities & 24.4 & -42.5 & 60.4 & 21.0 & -13.0 & 5.4 & -1.4 & 8.4 & $4-17.3$ & 18.8 & 321.5 & -5.5 & -20.1 & 6.7 \\
\hline REITs & -13.5 & -51.9 & 62.1 & 25.6 & 4.0 & 23.0 & 0.4 & 11.2 & 6.8 & 2.1 & 1.5 & 13.6 & -23.4 & 7.1 \\
\hline
\end{tabular}

2. The EA strategy has performed relatively well through the recent market sell-off. The EA was established with a "conservative diversified" strategy to provide a potentially meaningful contribution to the Fund's income while preserving the portfolio's long-term real value. To this end, the EA's asset allocation maintains a large exposure to fixed income with a notable allocation (20 percent) to inflation-linked bonds (US TIPS). While US TIPs have performed less well than nominal bonds given declining inflation expectations, they have outperformed equities in the recent sell-off. Comparable long-term investors such as pension funds and university endowments usually hold a larger allocation to equities or other risk assets, and would have experienced larger drawdowns and higher return volatility than the EA. The investment arrangements for the passive component of the EA have also protected portfolio performance. The passive arrangements recently adopted by the Investment Oversight Committee for the corporate bond allocation target a fixed average credit quality which is higher than the market average. As a result, the EA's corporate bond 
investments have suffered fewer downgrades and performed better than a market-capitalization weighted index.

\section{Given the scale of the equity} market sell-off, the EA return for the fiscal year is likely to be negative

(Figure A1.2). At the end of March, the subaccount's return for the fiscal year stood at -4.11 percent, in USD terms. The EA's annualized real return since inception is now just over 1 percent. As discussed by the Board during the 2018 Review of the IA, the EA's long-term real return target of 3 percent has been, and remains, challenging in an environment with bond yields at historically low levels.

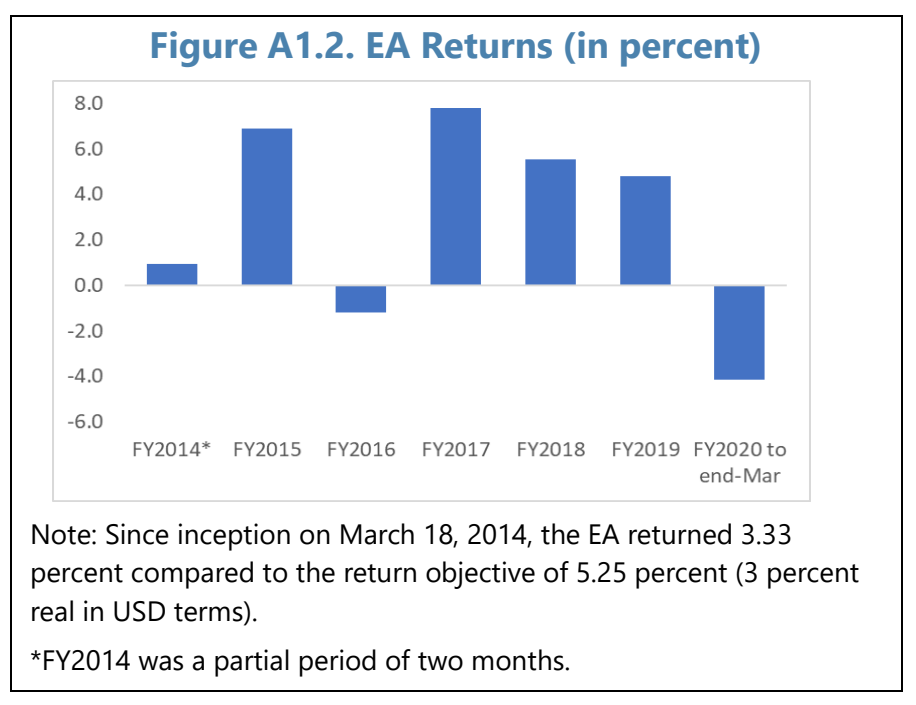

\section{Fixed-Income Subaccount (FI)}

\section{Central banks' emergency policy responses to the building crisis have driven SDR} weighted government bond yields to historically low levels. Two-year SDR government bond yields are currently around $9 \mathrm{bps}$, only marginally above the SDRi floor of $5 \mathrm{bps}$. The precipitous drop in yield levels was beneficial for the FI's SDR government bond holdings. At the same time, many investors rushed to raise cash through selling short-dated credit assets, such as asset-backed securities, mortgage-backed securities, and corporate bonds. This caused a dramatic widening of credit spreads and mark-to-market losses on short-duration credit assets, although these losses are expected to be temporary in nature.

\section{Overall, the Fl investment strategy demonstrated its resiliency through this credit crisis. The}

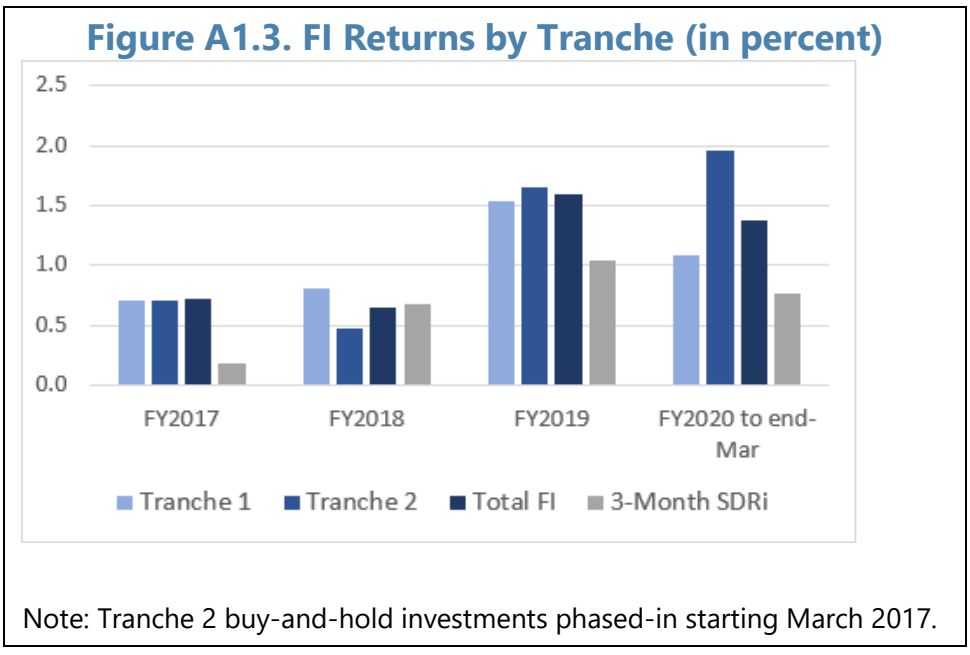
strategy, which aims at generating income over the SDR interest rate while protecting the Fund's balance sheet, has worked as intended with its two-tranche structure balancing short-duration credit exposure (Tranche 1) with longer duration buy-and-hold investments in highly-rated government bonds (Tranche 2). The mark-to-market losses from credit assets held by managers in Tranche 1 were offset by gains on longer duration government bonds in Tranche 2. In addition, the flexibility allowed in Tranche 1 enabled the managers to pursue distinct strategies which enhanced the 
portfolio's diversification and enabled them to adjust risk positions to quickly changing market conditions.

6. The $\mathrm{Fl}$ is likely to achieve an overall positive return for the fiscal year and maintain a solid margin above the SDRi (Figure A1.3). For the fiscal year through the end of March, the FI had generated a return of 1.45 percent, 69 bps greater than the average SDRi. 


\section{Annex II. Assumptions Underlying the Income Projections}

\section{Assumptions Underlying the Income Projections \\ (in billions of SDRs, unless otherwise stated)}

\begin{tabular}{|c|c|c|c|c|}
\hline & \multicolumn{4}{|l|}{ Actual } \\
\hline & through & FY & FY & FY \\
\hline & Mar. 2020 & 2020 & 2021 & 2022 \\
\hline \multicolumn{5}{|l|}{ Regular Facilities: } \\
\hline 1. Purchases (excl. reserve tranche purchases) & 8.6 & 19.5 & 24.9 & 2.5 \\
\hline 2. Repurchases & 6.6 & 6.9 & 3.2 & 10.7 \\
\hline 3. Average balances subject to charges & 66.5 & 66.7 & 96.1 & 95.1 \\
\hline 4. Average SDR holdings & 22.1 & 22.1 & 22.3 & 23.3 \\
\hline 5. Average remunerated positions & 71.5 & 71.9 & 102.7 & 104.6 \\
\hline 6. Average investment account assets-Fixed-Income subaccount & 16.6 & 16.6 & 16.5 & 16.8 \\
\hline 7. Average investment account assets-Endowment subaccount & 5.4 & 5.4 & 5.4 & 5.5 \\
\hline \multirow[t]{2}{*}{ 8. Average borrowings and issued notes } & 11.3 & 11.1 & 8.4 & 6.3 \\
\hline & \multicolumn{4}{|c|}{ (In percent) } \\
\hline Return on investments-Fixed-Income subaccount ${ }^{1}$ & 1.45 & 1.53 & 0.31 & 0.41 \\
\hline Return on investments-Endowment subaccount ${ }^{1,2}$ & -2.74 & -2.30 & 3.16 & 3.22 \\
\hline \multicolumn{5}{|l|}{ Average interest rates: } \\
\hline SDR interest rate and basic rate of remuneration & 0.8 & 0.8 & 0.1 & 0.1 \\
\hline Basic rate of charge & 1.8 & 1.8 & 1.1 & 1.1 \\
\hline Margin on the rate of charge & 1.0 & 1.0 & 1.0 & 1.0 \\
\hline
\end{tabular}

\section{CInternational Monetary Fund. Not for Redistribution}




\section{Annex III. Consolidated Medium-Term Income and Expenses}

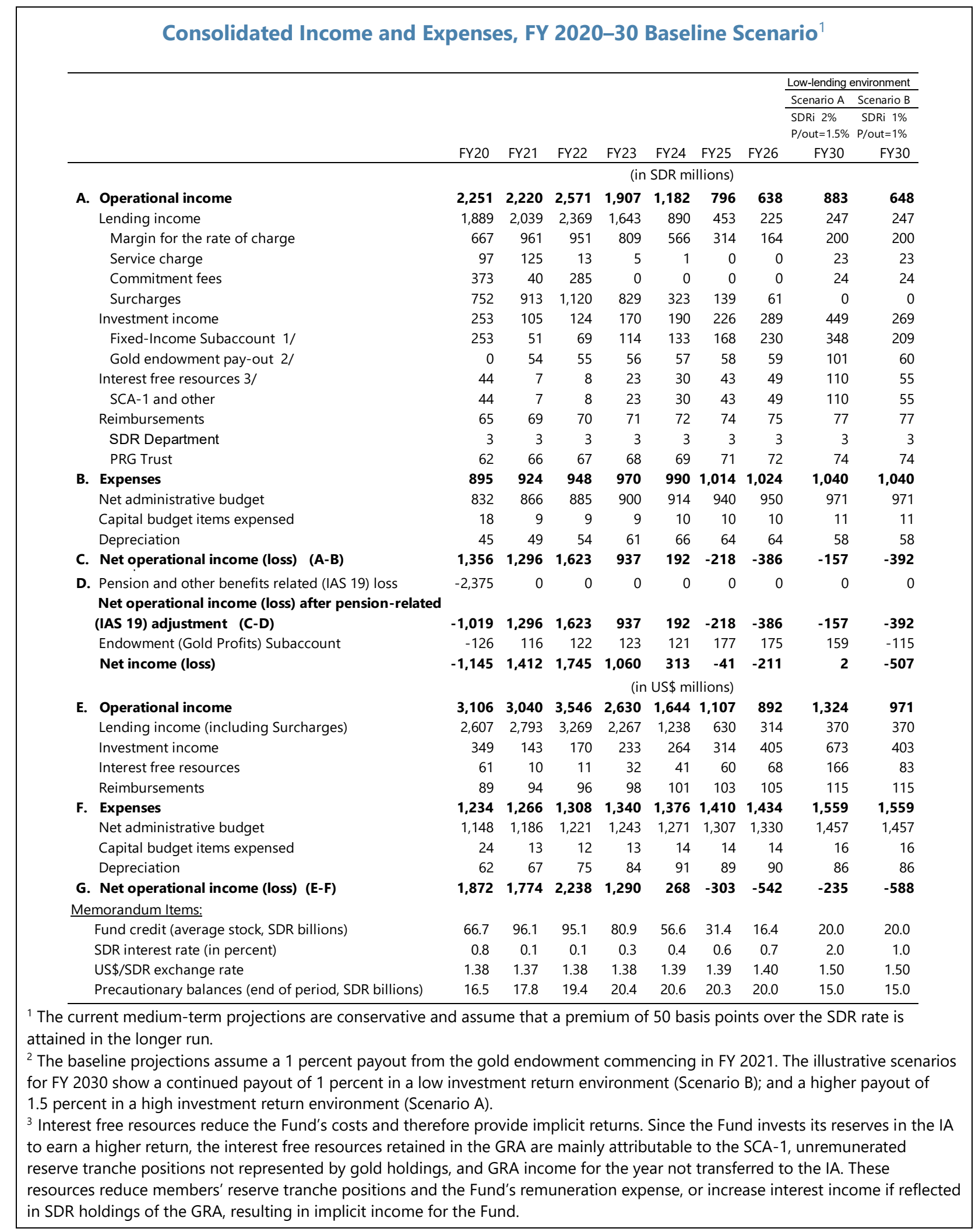

